\title{
Policy Overview and Options for Maximizing the Role of Policy in Geothermal Electricity Development
}

Technical Report NREL/TP-6A2-46653

September 2009

Elizabeth Doris, Claire Kreycik, and Katherine Young 


\section{Policy Overview and Options for Maximizing the Role of Policy in Geothermal Electricity Development}

Technical Report NREL/TP-6A2-46653

September 2009

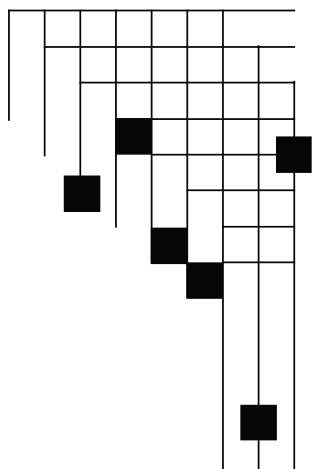




\section{NOTICE}

This report was prepared as an account of work sponsored by an agency of the United States government. Neither the United States government nor any agency thereof, nor any of their employees, makes any warranty, express or implied, or assumes any legal liability or responsibility for the accuracy, completeness, or usefulness of any information, apparatus, product, or process disclosed, or represents that its use would not infringe privately owned rights. Reference herein to any specific commercial product, process, or service by trade name, trademark, manufacturer, or otherwise does not necessarily constitute or imply its endorsement, recommendation, or favoring by the United States government or any agency thereof. The views and opinions of authors expressed herein do not necessarily state or reflect those of the United States government or any agency thereof.

Available electronically at http://www.osti.gov/bridge

Available for a processing fee to U.S. Department of Energy and its contractors, in paper, from:

U.S. Department of Energy

Office of Scientific and Technical Information

P.O. Box 62

Oak Ridge, TN 37831-0062

phone: 865.576 .8401

fax: 865.576 .5728

email: mailto:reports@adonis.osti.gov

Available for sale to the public, in paper, from:

U.S. Department of Commerce

National Technical Information Service

5285 Port Royal Road

Springfield, VA 22161

phone: 800.553.6847

fax: 703.605.6900

email: orders@ntis.fedworld.gov

online ordering: http://www.ntis.gov/ordering.htm 


\section{Acknowledgments}

This report is made possible by the U.S. Department of Energy's (DOE's) Geothermal Technology Program (GTP). The authors thank Doug Arent, Ted James, Margaret Mann, and Charlie Visser (NREL); Arlene Anderson, Hildigunnur Thorsteinsson, and Nicole Reed (DOE GTP); and Karl Gawell (Geothermal Energy Association) for comments on drafts throughout the process. The authors also thank Karen Atkison for technical and style edits. Of course, any remaining errors or omissions are the responsibility of the authors. 


\section{List of Acronyms}

$\begin{array}{ll}\text { ARRA } & \text { American Recovery and Reinvestment Act of } 2009 \\ \text { BLM } & \text { Bureau of Land Management } \\ \text { CREB } & \text { Clean Renewable Energy Bond } \\ \text { DOE } & \text { Department of Energy } \\ \text { DOI } & \text { U.S. Department of Interior } \\ \text { EGS } & \text { Enhanced Geothermal Systems } \\ \text { EPAct } & \text { Energy Policy Act } \\ \text { FIT } & \text { Feed-In-Tariffs } \\ \text { FOA } & \text { funding opportunity announcement } \\ \text { GRDA } & \text { Geothermal Resources Development Account } \\ \text { GTP } & \text { DOE Geothermal Technologies Program } \\ \text { ITC } & \text { investment tax credit } \\ \text { kW } & \text { kilowatts } \\ \text { LCOE } & \text { levelized cost of energy } \\ \text { MACRS } & \text { Modified Accelerated Cost Recovery } \\ \text { MWe } & \text { megawatts (electric) } \\ \text { NREL } & \text { National Renewable Energy Laboratory } \\ \text { PEIS } & \text { programmatic environmental impact statement } \\ \text { PTC } & \text { production tax credit } \\ \text { PURPA } & \text { Public Utilities Regulatory Policies Act } \\ \text { QF } & \text { qualified facility } \\ \text { RD\&D } & \text { research, development, and demonstration } \\ \text { REAP } & \text { Rural Energy for America Program } \\ \text { RPS } & \text { Renewable Portfolio Standard } \\ \text { RPS } & \text { renewable portfolio standard } \\ \text { USFS } & \text { United States Forest Service } \\ \text { USGS } & \text { United States Geological Survey } \\ & \end{array}$




\section{Table of Contents}

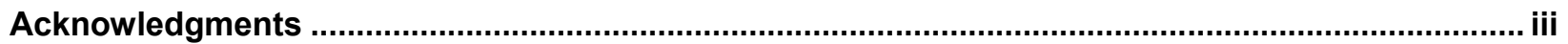

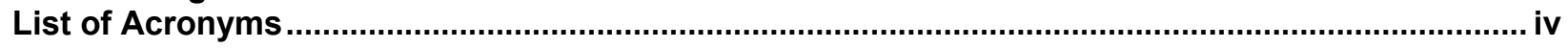

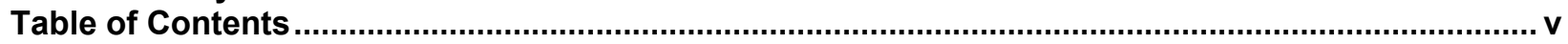

Chapter 1. Summary and Introduction..................................................................................... 1

Chapter 2. Historical and Current Policies Influencing Geothermal Development and the Gaps

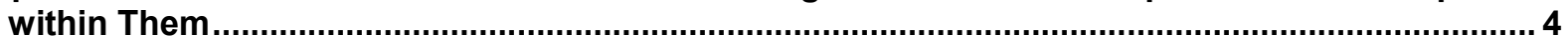

2.1 Review of Geothermal Development and the Role of Policy ........................................6

2.1.1 Research, Development \& Demonstration Investments .......................................

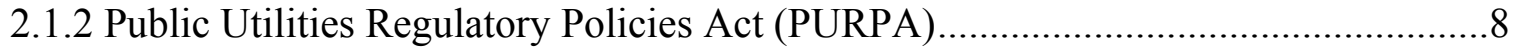

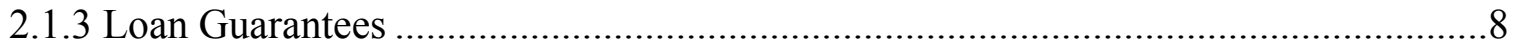

2.1.4 Investment Tax Credits (ITCs) .....................................................................

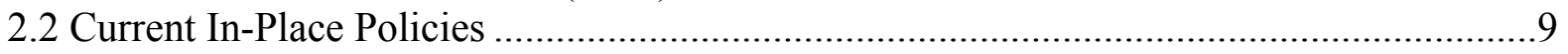

2.2.1 Federal Barrier-Reduction Policies ................................................................... 10

2.2.2 Federal Funding Opportunities and Financial Incentives ....................................12

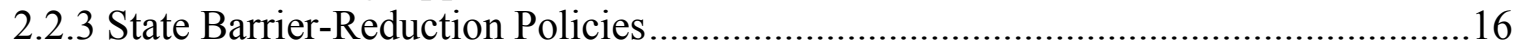

2.2.4 State Financial Incentives ......................................................................... 18

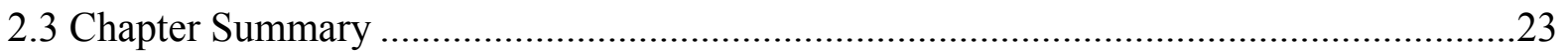

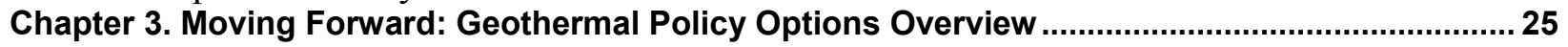

3.1 Gaps and Opportunities in Current Policy Structure ....................................................25

3.1.1 Geothermal-Specific Policies and In-Policy Carve Outs.....................................25

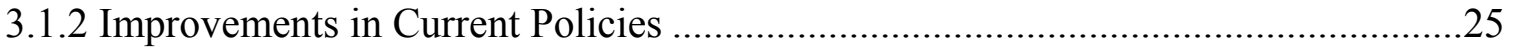

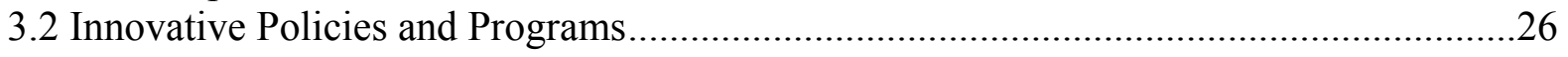

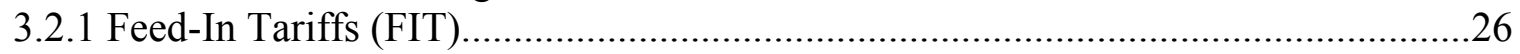

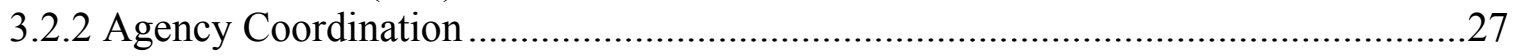

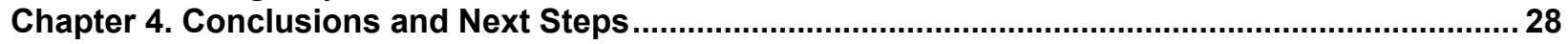

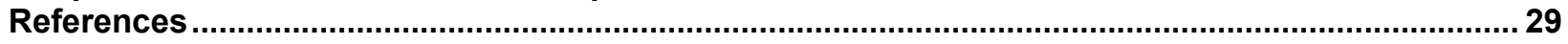

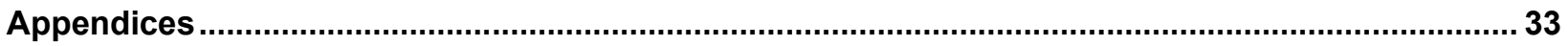

Appendix 1. Case Study: The Federal Production Tax Credit and Geothermal Development33

Appendix 2. Renewable Portfolio Standard and Geothermal Development in Nevada and

California 


\section{Chapter 1. Summary and Introduction}

Geothermal electricity production ${ }^{1}$ capacity has grown over time because of multiple factors, including its renewable, baseload, and domestic attributes; volatile and high prices for competing technologies; and policy intervention. Overarching federal policies, namely the Public Utilities Regulatory Policies Act (PURPA), ${ }^{2}$ provided certainty to project investors in the $1980 \mathrm{~s}$, leading to a boom in geothermal development. In addition to market expansion through PURPA, research and development policies provided an investment of public dollars toward developing technologies and reducing costs over time to increase the market competitiveness of geothermal electricity. Together, these efforts are cited as the primary policy drivers for the currently installed capacity (Fleischmann 2007).

In the United States, more than 2,000 megawatts electric (MWe) have been developed since 1960. Still, there is evidence that the amount of geothermal resource is large relative to the current electric capacity (Kreycik, Doris, and Vimmerstedt, forthcoming). Today, changes to PURPA and inconsistent funding levels for research and development have slowed growth in geothermal electricity development, despite highly volatile electricity prices, an abundant resource, and public interest surrounding local and diverse resources. This research explores the effectiveness of the historical and current body of policies in terms of increased geothermal electricity development. Insights are provided into future policies that may drive the market to optimize development of available geothermal electricity resources.

Policy has the potential to drive the development of renewable energy resources through technology development, risk reduction, barrier reduction, and price equalization. ${ }^{3}$ Development of the geothermal resource markets require the following of public policy:

- Long-term (multi-year) upfront cost defrayment to reduce risk and provide support until power production begins

- Targeted policies in accordance with resource availability

- Appropriately sized incentives to meet the needs of the full range or some portion of the range between 250 kilowatts $(\mathrm{kW})$ to multi-megawatt facilities

- Appropriate recognition of the environmental and load benefits of baseload renewable energy generation.

\footnotetext{
${ }^{1}$ This paper focuses on electricity production from geothermal resources. Ground source heat pumps and other direct applications are not considered. Electricity generation includes the range of known technologies from conventional hydrothermal power through enhanced geothermal systems (EGS). Geothermal resources are widely available, though at varying degrees of electricity-generation potential. Conventional hydrothermal resources are currently used in the western half of the United States, but the potential for EGS may be extensive nationwide. In addition to broad potential applicability, using geothermal resources for electricity generation provides a low carbon, non-variable source of fuel-cost-free baseload capacity (GTP 2009)

${ }^{2} 16$ U.S.C. Sections 2601-2645.

${ }^{3}$ Note: This report covers incentives for the development of renewable electricity development from geothermal energy. Barriers that apply across all electricity development, such as transmission development incentives that may be critical to large-scale market penetration of renewable resources, are beyond the scope of this report. However, several regional organizations, such as the Western Governors Association, are researching such issues.
} 
In the case of electricity generation from geothermal resources, the relationship between the historical role of state and federal policy in geothermal project development is not quantitatively clear in meeting these needs. In this paper, the potential role of policy with respect to other factors that influence renewable development in general are discussed, and then more specifically geothermal resource development. Then historical and current policies used by the federal and state governments are explored to promote geothermal power and identify gaps within those policies (Chapter 2), as well as opportunities for improving and expanding the role of policy in geothermal electricity development (Chapter 3).

Findings indicate that existing federal and state policies do not provide the comprehensive and consistent policy environment that is necessary to spur on development of geothermal electrical generation. Specifically, the current set of policies:

(1) Lacks focus on the special needs of geothermal resource development

(2) Lacks adequate financial resources to support market expansion and development

(3) May be targeting a limited or incorrect audience (e.g., providing residential-scale incentives instead of utility incentives for large projects).

More appropriate policies at the federal and state level could foster technology development and increased investment by the private sector, spurring geothermal resource development.

Opportunities to improve and expand geothermal power policy include:

- Streamlining and updating federal policies governing geothermal leasing, permitting, and drilling on federal lands. The recent Bureau of Land Management (BLM) and U.S. Forest Service (USFS) efforts to streamline leasing of BLM land are an example of new policies being implemented to reflect interest in increasing geothermal electricity development. ${ }^{4}$ Continued development of coordinated agency activities in the streamlining of electricity generation for geothermal resources, especially emerging technologies, could lead to increased market penetration.

- Designing state-specific policies with geothermal-specific attributes. Such attributes could include geothermal "set asides" in renewable portfolio standards that require geothermal resources to be used for a percentage of the renewable portfolio mandate. Although there is limited experience in "set asides" for geothermal, this strategy has been successful in opening markets for solar in other states (Wiser and Barbose 2008).

- A better understanding of the federal and state ownership, legislative, and regulatory rules regarding geothermal resources and their development. The American Recovery and Reinvestment Act (ARRA) specified development of a data system for geothermal information (outlined in the body of this paper). This effort may provide the beginnings of a dataset that could reduce information barriers for investors and developers, thereby creating an incentive for developers.

\footnotetext{
${ }^{4}$ The BLM/USFS Record of Decision and Resource Management Plan Amendments for Geothermal Leasing in the Western United States (BLM 2008) is an example. This record streamlines leasing for geothermal electricity projects by categorizing BLM land areas open and closed to drilling, identifies areas targeted for development (focused only on hydrothermal technologies), and identifies best practices for land management in the context of geothermal development. The record does not address permitting and drilling.
} 
- Exploring innovative and emerging policies, such as feed-in tariffs (FIT), that can provide equitable, consistent support to renewable technologies. FITs provide fixed-price payments, differentiated by technology, to power producers on a per-kilowatt-hour basis. FIT policies can be considered as an augmentation or alternative to current financial incentive policies. Because of the potential transparency and investor confidence they provide, FITs could be a powerful support mechanism for geothermal development.

More research connecting the role of policy to geothermal resource development is necessary to understand the impacts of enhancing geothermal policies. Primary topics to provide more insights are as follows:

- At the federal level, there are two primary areas for analysis:

- A rigorous and quantitative understanding of the impact of policy on directing research and demonstration (R\&D) over time to determine if policies create risk reduction and private sector uptake.

- Additional research to understand policy impacts for increasing access to federal lands for renewable energy projects to determine if the benefits of geothermal power production outweigh the potential drawbacks (e.g., ecological impact). The December 2008 BLM/USFS Record of Decision (BLM 2008) on leasing requires evaluation for impact of those revised policies on geothermal development.

- At the state level, there are three primary directions for improving policy coverage:

- Identify state policies with the highest impact on development of geothermal power production. Understanding policy design, impacts of policies, and aspects of policies that specifically target geothermal is necessary for better informing policy design.

- Understand the role of policy in different resource and economic contexts. (Resource contexts could include both high and low temperature geothermal energy, as well as hydrothermal and direct use applications.)

- Estimate the impact of potentially innovative policies that states could implement to promote geothermal development and power production.

In addition to these independent federal and state research needs, informing policy decisions depends on the combined impacts of policies at the federal and state level on geothermal development. Identifying high-impact suites of policies for different contexts, and the government levels best equipped to implement them, would provide a wealth of information to both policy makers and project developers. 


\section{Chapter 2. Historical and Current Policies Influencing Geothermal Development and the Gaps within Them}

Renewable energy development is driven by a number of interacting factors (Figure 1). It is therefore a challenge to identify the most effective policies for encouraging development of resources (Brown and Busche 2008, Doris et al. Forthcoming). In addition to these factors, different policies have different impacts along the technology development continuum from hydrothermal to enhanced geothermal systems (EGS). This in turn increases the difficulty in identifying the appropriate policy to maximize technology application. This chapter provides an overview of the major policy development challenges surrounding geothermal and then the historical (Section 2.1) and current (Section 2.2) policies intended to influence geothermal resource and technology development are reviewed.

Terminology presents a major challenge in evaluating historical and current policies' impact on geothermal development. As noted in the introduction, this research focuses on geothermal resources for electricity production, ${ }^{5}$ not direct-use or ground source heat pumps (a.k.a. geothermal heat pumps). Direct-use technologies pipe hot water from deep in the earth for direct uses such as heating buildings, aquaculture, and crop drying. Ground source heat pumps are heat exchangers connected to an in-ground, shallow (10-20 feet deep) pipe system that takes advantage of the relatively constant temperature of the earth to provide heating and cooling in residential and commercial applications. Neither of these geothermal resource uses produce electricity.

It is clear that there are technological difference between these technologies and the technologies on the continuum from hydrothermal to EGS that convert the earth's heat into electricity. However, policy recognition of the difference is lacking. In general, historical and current policies lump all types of resource use together. Because of the differences in technology scale, end use, costs, and degree of commercialization, the effectiveness of the general incentives could be minimized. For example, several state incentives offer a several-hundred-dollar rebate to geothermal technologies. Rebates at such a low level will not significantly impact single to multi-megawatt geothermal electricity production facilities that cost millions of dollars to develop and take years to get to production of electricity. However, these policies apply to all types of these earth-based technologies, under the nomenclature of geothermal technologies. Because these policies could apply to all technologies, they are all listed in this report, but the next steps suggest a separation of the policies identifying primary target technologies to better understand how different policies affect each of the technologies' market penetration.

There is another major challenge in the use of policy for developing geothermal resources for electricity: the specific resource and technology attributes combine to form unique opportunities for policy intervention to correct market barriers that face both fossil and renewable electricity production. These attributes include:

- Geothermal resource can provide baseload electricity production

- Geothermal is resource location dependant

\footnotetext{
${ }^{5}$ Including, but not limited to, multiple geothermal technologies such as hydrothermal, EGS, co-production, geopressured, low temperature, and distributed generation.
} 
- Geothermal can be both utility and distributed scale

- Geothermal electricity can be produced on the distributed (approximately $250-\mathrm{kW}$ ) and utility (multi-megawatt) scales

- Geothermal power plant development can take years, incurring high first costs and high risk to investors for long periods of time.

As a result of the combination of all these attributes, policy designs targeting these opportunities could be the most effective at promoting development of the resource. These policy designs might include specific attributes to meet the needs of geothermal development, including:

- Long term (multi-year) upfront cost defrayment to reduce risk and provide support until power production begins

- Targeted policies in accordance with resource availability

- Appropriately sized standards and incentives to meet the needs of $250-\mathrm{kW}$ to multimegawatt facilities

- Appropriate recognition of the environmental and load benefits of baseload renewable energy generation.

In the remainder of this chapter an overview of the historical and current policies that can be applied to geothermal resources is provided. Limited observations are made on the effectiveness of policies related to major increases in market penetration for geothermal electricity based on available data. Chapter 3 provides insights into the potential policy attributes that may have a large impact on the market and identifies where additional and different policies could better fill existing policy gaps. 


\section{Factors Affecting Renewable Energy Markets}

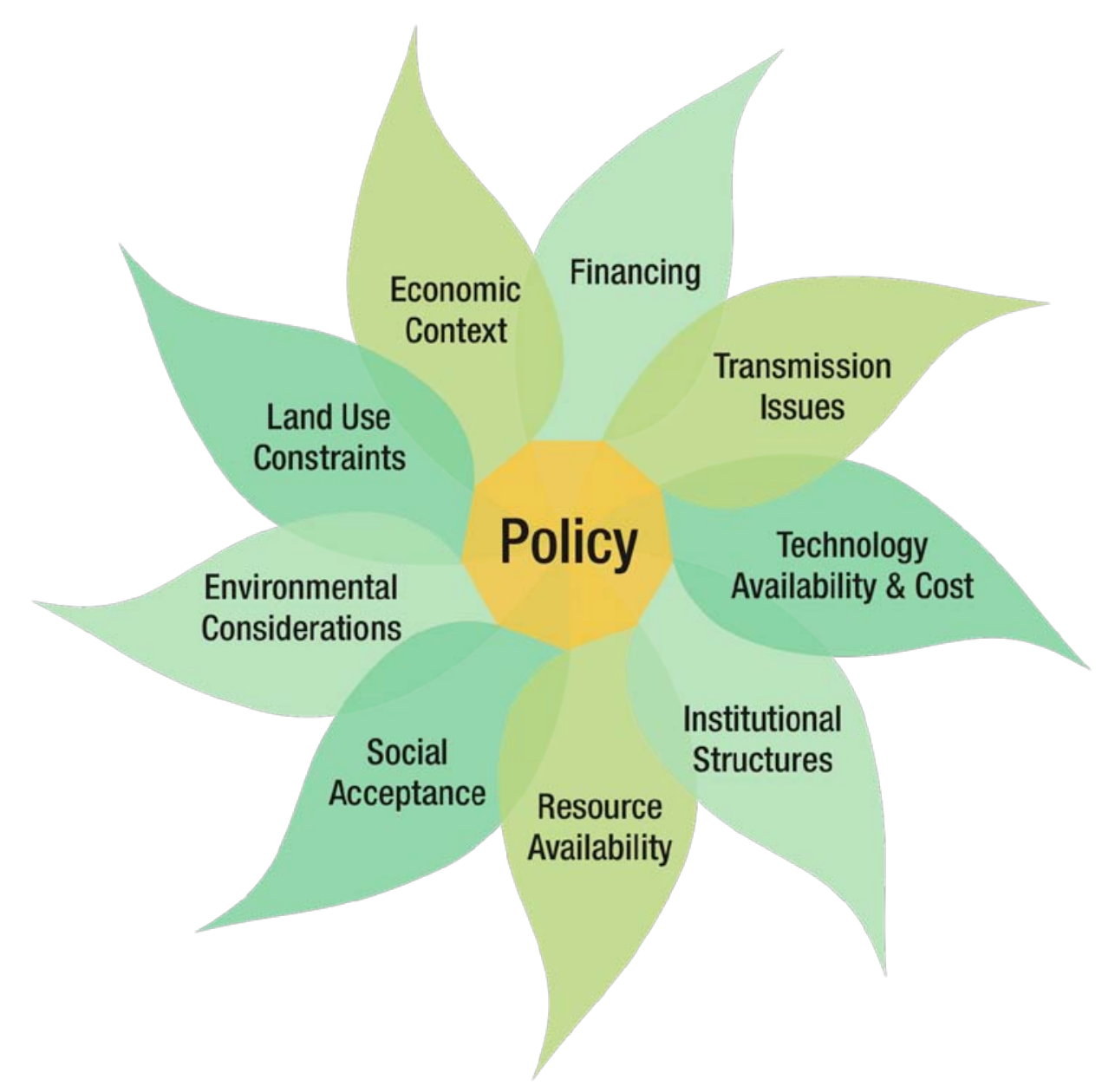

Figure 1. Concept drawing of contextual factors influencing renewable energy development

\subsection{Review of Geothermal Development and the Role of Policy}

The first major surge of geothermal resource development occurred between 1979 and 1992 , during which more than 50 geothermal power plants were installed in three states (Fleischmann 2007). During this time, interest in domestic energy resources increased as a result of the 1973 oil embargo and subsequent high energy prices. In reaction, the federal government implemented four primary types of policies directed at the development of the geothermal electricity market:

1) Investment in research, development and demonstration (RD\&D)

2) Mandating utilities to purchase renewable power at avoided costs through the Public Utilities Regulatory Policies Act (PURPA)

3) Loan guarantees

4) Investment tax credits (ITCs). 
While all four of these incentives intended to encourage private-sector investment in the full range of geothermal technology, RD\&D and PURPA were the primary drivers due to the scale and scope of those programs.

\subsubsection{Research, Development \& Demonstration Investments}

Development of geothermal resources has been promoted at the federal level through RD\&D investment policies. RD\&D investments from the public sector are correlated to increased patents, an indication of private-sector investment in technology development (Margolis and Kammen 1999). Public-sector funding for geothermal demonstration is critical to larger electricity installations because these require extensive siting and permitting processes, and public-sector involvement can reduce risk of failure along the project development pipeline.

Public, policy-driven RD\&D funds are directed along the continuum of geothermal technology development, from initial laboratory development to resource characterization, exploration, and cost-shared drilling and energy conversion technologies. The late 1970s and early 1980s experienced rapid growth in geothermal development that coincides nearly directly with increased RD\&D funding (Figures 2 and 3), indicating that general RD\&D findings from Margolis and Kammen (1999) likely apply to geothermal technologies.

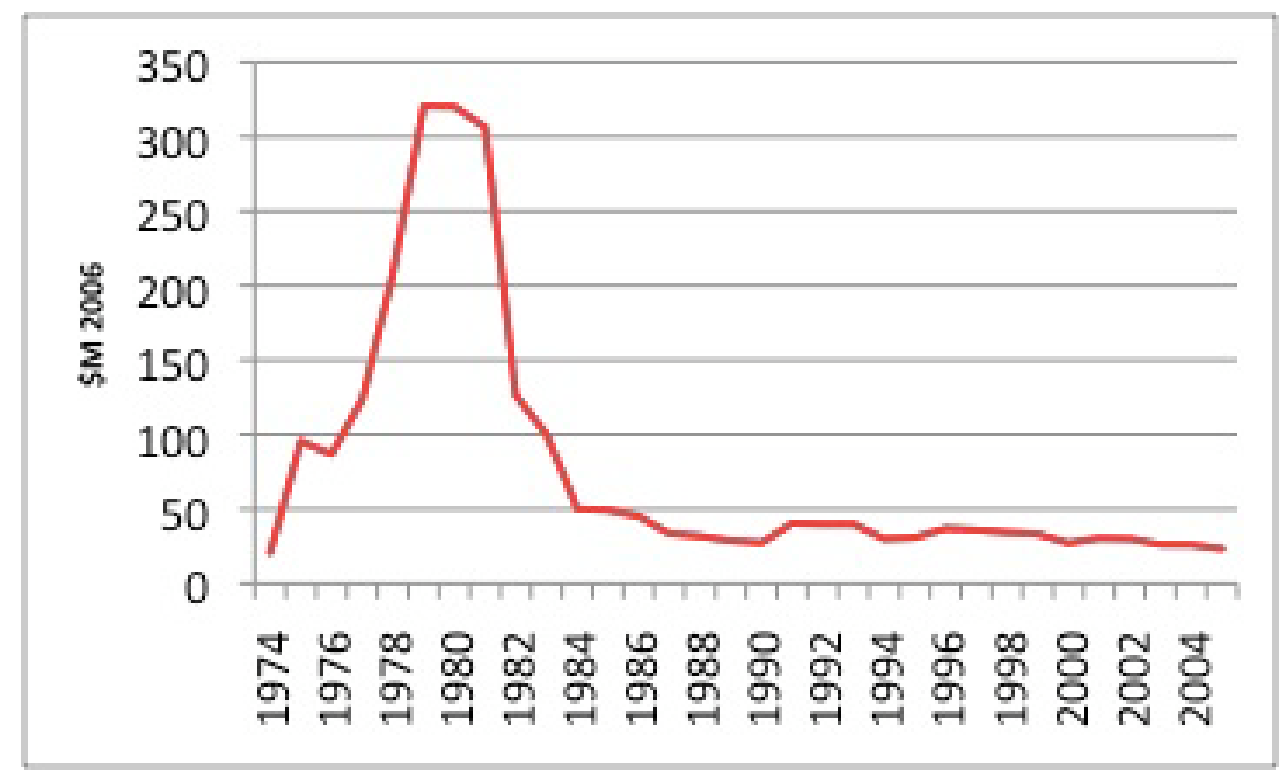

Figure 2. Public geothermal RD\&D funding from 1974-2005. See Figure 3 for comparison with development. (Source: IEA Statistical Database) 


\subsubsection{Public Utilities Regulatory Policies Act (PURPA)}

In addition to RD\&D funds, the federal government promoted the geothermal market through the federal passage and state implementation of PURPA in 1978, which required utilities to purchase renewable power at avoided power costs. ${ }^{6}$ Under PURPA, contracts provided fixed payments for both energy and capacity to allow projects to obtain financing. At the time of issuance of these contracts, natural gas prices were high and projected to rise, so utility avoided cost was high, and the development of geothermal resources was economically viable given the guarantee of the power purchase. Geothermal development surged during the early years of PURPA from 1978 through 1989; almost 30 contracts were executed for more than $600 \mathrm{MWe}$ of new capacity in California alone (EIA 1995). Although PURPA is still enacted, its policy impact dwindled in the 1990s due to a decrease in utility avoided costs with the drop of natural gas prices.

\subsubsection{Loan Guarantees}

Loan guarantees are mechanisms that reduce investment risk by guaranteeing that the loan will be repaid by the federal government if the company defaults on the loan. The geothermal loan guarantee program was available between 1978 and 1982 and applied to both direct-use and electricity-producing technologies. The program dispersed \$139.6 million in loan guarantees, only $47 \%$ of the guarantee limit. Of that, about $\$ 100$ million was repaid by the applicants; debtors defaulted on $\$ 39$ million, which was repaid by the government. Out of nine applicants to the program, four projects were not completed, three were successfully completed for direct use, and two hydrothermal power plants were completed (NCPA and ORMESA 1) for a total of 140 MWe. Both successful electricity generation projects had significant existing financial resources (the loan guarantee covered less than $50 \%$ of project costs), indicating that the loan guarantee program singly was not responsible for project success, but could be applied successfully in niche markets. In 1982, the program was terminated due to inconclusive evidence of impact (especially relative to PURPA impacts) and the remaining funding was redirected, although existing applicants to the program were honored with continued guarantees (Levite et al. 2005). ${ }^{7}$

\subsubsection{Investment Tax Credits (ITCs)}

Finally, the federal government also worked to develop the geothermal market through ITCs from 1978 through 1986. The Energy Tax Act, passed in 1978, made a 10\% investment tax credit available to geothermal developers. The impact of the tax credit is uncertain due to limited data on the number or size of the projects that took advantage of it. The Energy Tax Act is not generally considered to be a major driver in geothermal energy development relative to PURPA and $\mathrm{R} \& \mathrm{D}$; therefore it is not explored further in this report.

Despite the early explosion of geothermal development in the 1970s and 1980s, resource development continues to be dwarfed by resource availability. After the R\&D investment and subsequent increase in geothermal development through the 1980 s, a period of relative stagnancy

\footnotetext{
${ }^{6}$ Avoided costs are the marginal costs to the utility of providing one more unit of power. Put another way, it is the cost that the utility would pay if it were using it's own generation capability or purchasing it from another provider. ${ }^{7}$ This continuation of the program means that the short duration of the program would not have an impact on the projects accepted to it.
} 
occurred from 1992 to 2005, where fewer new geothermal projects were developed (Fleischmann 2007). Most added capacity during this period was due to expansion of existing projects, like Salton Sea in California and Steamboat in Nevada (GEA 2008a) (Figure 3). ${ }^{\mathbf{8}}$

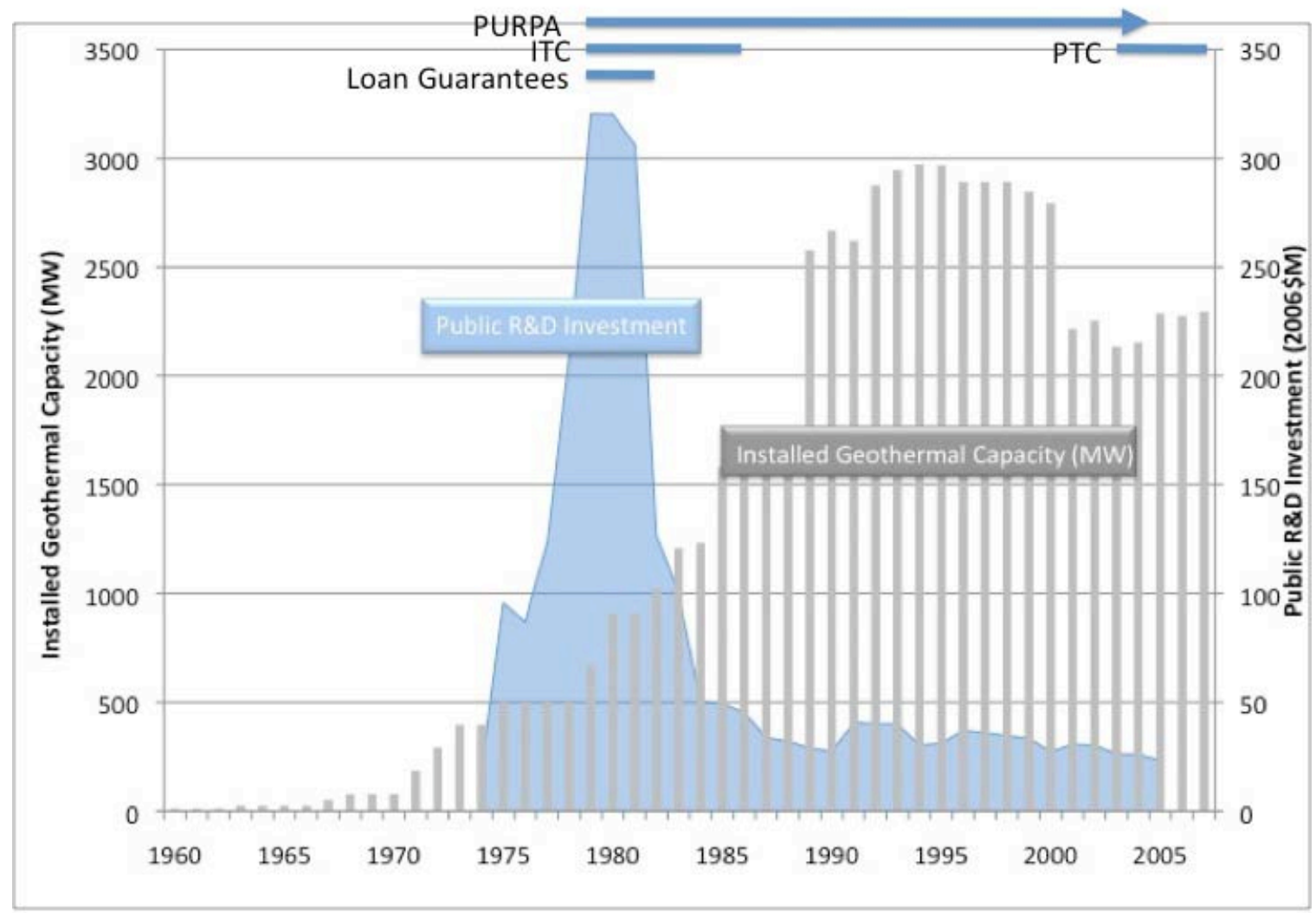

Figure 3: Installed Geothermal Capacity (MW) 1960-2007, R\&D investment (\$M 2006) and select federal policies. Apparent drop in capacity around the year 2000 results from a combination of 1) a change in data collection and reporting methods within the Energy Information Administration at the DOE, resulting in apparent reduced capacity (but not actually) and 2) an actual retirement of capacity. This report assumes that growth flattened in the 1990s and the data discrepancy is not an actual drop in capacity.

\subsection{Current In-Place Policies ${ }^{9}$}

A recent resurgence in geothermal project development results from increased interest in domestic resources, high and volatile energy prices, and an interest in lower environmental impact energy choices. Today 103 hydrothermal plants are under development in 13 states (GEA 2008b). As before, policy drivers appear to largely impact geothermal development. Key polices include:

\footnotetext{
${ }^{8}$ Apparent drop in capacity around the year 2000 results from a combination of 1) a change in data collection and reporting methods within the Energy Information Administration at the DOE resulting in apparent reduced capacity (but not actually) and 2) an actual retirement of capacity. This report assumes that growth flattened in the 1990s and the data discrepancy is not an actual drop in capacity.

${ }^{9}$ This report does not cover proposed or pending federal legislation.
} 
(1) The availability of the federal production tax credit (PTC), opened to geothermal energy in 2004 for a portion of the wind credit and to the full credit in 2005.

(2) The existence of state renewable portfolio standards (RPS) to augment the risk-reduction effects created by PURPA. In addition to the power-purchase risk reduction offered by PURPA and state-level RPSs, the revised federal geothermal leasing regulations (BLM 2008) are expected to expedite project timelines and drive the current market.

(3) State and utility financial incentives (e.g., state permitting expedition, tax abatement policies) are being implemented to draw developers into states (Lantz forthcoming). Due to the piecemeal process of policy development and the different reasons policies are put in place, there is no unified strategy for federal and state incentives promoting geothermal resource development.

The most recent additions to the policy landscape for geothermal production are the changes and updates to financial incentives for geothermal electricity generation in ARRA. The long-term impact of this policy development is not currently known due to the recent nature of the law.

The remainder of this section outlines current federal barrier reduction policies, federal incentive programs, state barrier reduction policies, and state incentive policies that apply to geothermal development.

\subsubsection{Federal Barrier-Reduction Policies}

The Energy Policy Act (EPAct) of 2005: This act had two primary provisions affecting geothermal energy production. First, it authorizes an update to a 1978 US Geological Survey (USGS) resource assessment. Second, EPAct 2005 outlines the process for unitization of geothermal resources by federal geothermal leaseholders.

The 1978 resource assessment identified geothermal resources for hydrothermal power generation that exist throughout the western United States, an area with a high percentage of federal lands. The new assessment of moderate- and high- temperature geothermal resources in 13 states identified 241 geothermal sites on private or accessible public lands in the western United States (USGS 2008). An estimated 90\% of the nation's hydrothermal resources are located on federal lands (DOI 2008). Because leasing public land has historically presented a challenge for developers, it is necessary for the government to facilitate their leasing and access to areas with known geothermal resources.

EPAct 2005 amended the leasing regulations for geothermal resources located on federal lands. The legislation requires that the bidding process be competitive (as opposed to sealed), which has opened up the resource nomination process to the market. The BLM is required to hold lease sales at least every two years to ensure that leasing applications are processed. Furthermore, the legislation required that a backlog of leasing applications prior to 2005 be processed. Finally, EPAct changed royalty shares between federal, state, and county governments to $25 \%, 50 \%$, and $25 \%$, respectively (GEA 2005).

Since passage of the bill, the BLM has held four auctions, summarized in Table 1. These auctions have yielded the highest per-acre bid in all of the BLM's historical auctions. 
Table 1. BLM Land Auction Size and Revenue for Geothermal Production

\begin{tabular}{|c|c|c|c|c|c|}
\hline Date & $\begin{array}{c}\text { Average } \\
\text { Price per } \\
\text { Acre }\end{array}$ & State & Acres & $\begin{array}{c}\text { Total } \\
\text { Revenue* } \\
\text { (\$M) }\end{array}$ & Price Per Acre \\
\hline \multirow[t]{2}{*}{ June 20, 2007} & \multirow[t]{2}{*}{$\$ 195$} & ID & 15,490 & $\$ 2.0$ & $\$ 129$ \\
\hline & & UT & 6,018 & $\$ 2.2$ & $\$ 366$ \\
\hline \multirow[t]{2}{*}{ Aug. 14, 2007} & \multirow[t]{2}{*}{$\$ 157$} & $\mathrm{CA}$ & 2,700 & $\$ 8.0$ & $\$ 2,963$ \\
\hline & & NV & 122,849 & $\$ 11.7$ & $\$ 95$ \\
\hline Aug. 5, 2008 & $\$ 268$ & NV & 105,211 & $\$ 28.2$ & $\$ 268$ \\
\hline \multirow[b]{3}{*}{\begin{tabular}{|l} 
July 13, 2009 \\
\end{tabular}} & \multirow[b]{3}{*}{$\$ 36$} & $\mathrm{CA}$ & 11,392 & $\$ 0.13$ & $\$ 12$ \\
\hline & & NV & 243,727 & $\$ 8.9$ & $\$ 37$ \\
\hline & & UT & 228 & $\$ 0.06$ & $\$ 251$ \\
\hline \multicolumn{3}{|l|}{ Total } & 507,615 & $\$ 61$ & \\
\hline
\end{tabular}

In 2007, the BLM's Deputy Director, Henri Bisson, stated that the new regulations related to auctions and leasing put the BLM in a good position to facilitate geothermal development, and that the shift to a competitive bidding process has led to a pivotal moment for renewable energy development on public lands (Renewable Energy World 2007). Beyond the auctions of available acreage, the BLM, in coordination with the Department of the Interior (DOI), released a new record for leasing decisions on BLM land (BLM 2008). This record, released on December 17, 2008, allocates BLM land available for drilling, identifies a reasonable development scenario for the land, and adopts best practices in leasing and management practices for the land. The record is expected to streamline and reduce transaction costs, thereby reducing investment risk in geothermal development.

The second provision having an impact on geothermal electricity production is the procedure outlined in EPAct 2005 for the holders of federal geothermal leases to unite to ensure efficient use of geothermal pools. Unitization allows for multiple landowners or federal leaseholders to combine the geothermal resource to reduce necessary investments in equipment and optimize the use of the resource through identification and exploitation of the most economic resources first. The regulations, released in their final version in 2007, define two types of agreements that can be made between federal leaseholders:

(a) Unit agreement. An agreement or plan of development and operation for the production and utilization of separately owned interests in the geothermal resources made subject thereto as a single consolidated unit without regard to separate ownerships and which provides for the allocation of costs and benefits on a basis defined in the agreement or plan.

(b) Cooperative agreement. An agreement or plan of development and operations for the production and utilization of geothermal resources made subject thereto in which separate ownership units are independently operated without allocation of production (43 C.F.R. Part 3280, CFR 2009). 
The unitization agreements outlined in the regulations specify the process the leaseholders use for unitization on federal lands, and represent agreements between the BLM and the entities holding the leases. Leaseholders must negotiate between themselves to identify the specific distribution of costs and benefits for each leaseholder, as this is outside the jurisdiction of the BLM. The process specifies that the unitizing leaseholders present a unit plan to the BLM for review and approval and the BLM officially establishes the geothermal production unit on federal land (Mastow and Braff 2008).

PURPA Standard Offer Contracts: PURPA was implemented beginning in 1978 and still drives some geothermal development. Since PURPA's inception, the avoided costs to utilities have declined, making geothermal less attractive for developers in pursuit of PURPA long-term contracts. There are some situations, however, where avoided costs are high enough to attract geothermal developers. In Idaho, for example, PURPA rules led to the development of the Raft River project (which came online in 2008) because avoided cost rates are higher than might be encountered in other states due to higher natural gas prices (Fleischmann 2006a).

Leasing Rights. Access to federal lands is limited due to environmental concerns. There are administrative and regulatory barriers for project developers to site their plant on public lands. Different requirements exist for BLM, USFS, and Tribal lands. Acquisition and leasing regulations vary depending on the type of federal land in question (GEA 2005).

To address this barrier the BLM completed an analysis on environmental impact in order to facilitate leasing processes (BLM 2008). This Programmatic Environmental Impact Statement (PEIS) defines appropriate resource-available areas, streamlines the leasing process and spells out best practices for project and land management for hydrothermal projects in the western United States (BLM 2008). This PEIS is the starting point for interagency coordination and public-private partnership in project development. A potential addition to the guide would be to legislate at the federal level that the BLM can assign geothermal rights to current oil and gas lease holders, which would allow the current lease holders to sell geothermal-based electricity back to the grid. Implementation of the guide and continued development of partnerships is critical to success of geothermal projects. Additionally, a PEIS addressing leasing issues with EGS projects and addressing the geographic breadth of the United States would increase the effectiveness of the coordination and broaden applicable technologies.

\subsubsection{Federal Funding Opportunities and Financial Incentives}

Research, Development, and Demonstration: The DOE's Geothermal Technologies Program currently funds R\&D and technical assistance for exploration and development (DOE 2008). Cost-shared drilling for exploratory wells helps geothermal projects become economical and draw in developers. Note that while historical and current geothermal projects have been hydrothermal in nature, RD\&D projects in 2008 focused solely on EGS: 17 industry projects were awarded funding for component EGS research and development, and 4 EGS demonstrations projects were awarded funding. This intentional shift in focus is aimed at promoting development of EGS projects in the United States. 
Federal Tax Incentives: Since 2005 the federal government has offered a production tax credit (PTC) for geothermal electricity production. The PTC provides a significant subsidy: $1.9 \notin / \mathrm{kWh}$ for 10 years for geothermal plants that are placed in service before the expiration of the credit program. In October 2008, the PTC expiration date was extended from December 31, 2008, to December 31, 2010, through the Emergency Economic Stabilization Act. In addition to the PTC, several other federal tax incentives are available, including the 10\% investment tax credit (ITC) for all expenditures on geothermal equipment except that required for transmission, and Modified Accelerated Cost Recovery System (MACRS), allowing for an accelerated depreciation on a 5 -year tax schedule, which amounts to approximately $15 \%$ investment incentive if the buyer has enough working capital. See Appendix 1 for a case study on the impact of the PTC.

In February 2009, passage of ARRA changed the role of the PTC and ITC for geothermal facilities. The section of ARRA most relevant to tax incentives for geothermal electricity production is section 1603, a U.S. Department of Treasury grant that allows taxable entities to take the $10 \%$ ITC or $30 \%$ PTC (technology dependant) as a cash grant. The $30 \%$ PTC is first converted to a $30 \%$ ITC, and then converted to the cash grant. Treasury guidance (U.S. Department of Treasury 2009) indicates that energy produced by a geothermal facility (e.g., the power plant equipment) is eligible for $30 \%$ of the cost basis and that $10 \%$ of the cost of the equipment used to derive the energy from the deposit (e.g., wells) is eligible (Table 2). The Treasury guidance also states that any overlap in the geothermal definitions in the tax codes results in either $30 \%$ or $10 \%$ of the facility being eligible, but not both. Other changes related to geothermal policy related to the ARRA are the extension of the production tax credit (PTC) should developers opt to take that instead of the Treasury grant - beyond 2009 to 2013 . The PTC is available to geothermal projects for 10 years, providing the facility is in use by 2013 . The long-term impacts of this economic stimulus-related legislation is unknown at this early stage of implementation, but given the length of time (years) for utility scale geothermal resource use to be realized, the new incentives may have the most impact on smaller-scale (approximately 250$\mathrm{kW}$ ) distributed geothermal technologies. 
Table 2. Geothermal Definitions in U.S. Code and Applicable Cost Basis Treasury Grant Program

\begin{tabular}{|c|c|c|c|}
\hline $\begin{array}{l}\text { Geothermal } \\
\text { Defined in } \\
\text { Section }\end{array}$ & Definition & $\begin{array}{l}\text { Applicable } \\
\% \text { of } \\
\text { Eligible } \\
\text { Cost Basis } \\
\end{array}$ & $\begin{array}{l}\text { Credit } \\
\text { Termination } \\
\text { Date }\end{array}$ \\
\hline $\begin{array}{l}\text { Geothermal } \\
\text { in IRC } \\
\text { Section } 45\end{array}$ & $\begin{array}{l}\text { Geothermal energy. The term "geothermal energy" } \\
\text { means energy derived from a geothermal } \\
\text { deposit (within the meaning of section } 613(\mathrm{e})(2) \\
[26 \text { USCS } \$ 613(\mathrm{e})(2)]) \text {. }\end{array}$ & $30 \%$ & Jan 1, 2014 \\
\hline $\begin{array}{l}\text { Geothermal } \\
\text { in IRC } \\
\text { Section } 48\end{array}$ & $\begin{array}{l}\text { (a,3,A,iii) equipment used to produce, distribute, } \\
\text { or use energy derived from a geothermal deposit } \\
\text { (within the meaning of section } 613(\mathrm{e})(2)) \text {, but only, } \\
\text { in the case of electricity generated by geothermal } \\
\text { power, up to (but not including) the electrical } \\
\text { transmission stage. }\end{array}$ & $10 \%$ & Jan 1, 2017 \\
\hline \multicolumn{4}{|c|}{$\begin{array}{l}\text { Notes } \\
26 \text { USC 613(e): Percentage depletion for geothermal deposits (1) In general in the case of } \\
\text { geothermal deposits located in the United States or in a possession of the United States, for } \\
\text { purposes of subsection (a) - (A) such deposits shall be treated as listed in subsection (b), and (B) } \\
15 \text { percent shall be deemed to be the percentage specified in subsection (b). (2) Geothermal } \\
\text { deposit defined for purposes of paragraph (1), the term "geothermal deposit" means a geothermal } \\
\text { reservoir consisting of natural heat which is stored in rocks or in an aqueous liquid or vapor } \\
\text { (whether or not under pressure). Such a deposit shall in no case be treated as a gas well for } \\
\text { purposes of this section or section } 613 \mathrm{~A} \text {, and this section shall not apply to a geothermal deposit } \\
\text { which is located outside the United States or its possessions. (3) Percentage depletion not to } \\
\text { include lease bonuses, etc. In the case of any geothermal deposit, the term "gross income from the } \\
\text { property" shall, for purposes of this section, not include any amount described in section } \\
613 \mathrm{~A}(\mathrm{~d})(5) \text {. Source: } \text { http://vlex.com/vid/sec-percentage-depletion-19209150, accessed August } \\
2009\end{array}$} \\
\hline
\end{tabular}

Federal Grants and Loans: The federal government implements several grant and loan programs for which geothermal electric systems are eligible. Geothermal projects can receive Tribal Energy Program grants and U.S. Department of Agriculture Rural Energy for America Program (REAP) grants. Additionally, the federal government provides loan guarantees for renewable energy projects, including development of geothermal resources, as listed in Title XVII of the EPAct 2005. Through 2005, the last year for which data is available, there are no geothermal electricity projects participating in the program (Walters et al. 2006).

Non-Tax Incentive ARRA Funding: In addition to the tax incentive changes for private companies previously listed, ARRA also provides $\$ 350$ million for geothermal research and demonstration, as well as funding for innovative exploration techniques. It is too early in the implementation of this ARRA funding to determine impacts of the policy. As of the writing of this report (September 2009), the following funding opportunity announcements (FOAs), valued at $\$ 275$ million ${ }^{10}$, have been released publically and closed: ${ }^{11}$

\footnotetext{
${ }^{10}$ There is also a $\$ 50$ million opportunity (closed August 6,2009 ) for geothermal heat pump demonstration projects, data collection and analysis, and the development of a national certification standard.

${ }^{11}$ See http://www.energy.gov/recovery/funding.htm\#RENEWABLE_ENERGY for more information
} 
- Validation of Innovative Exploration Technologies EISA Section 613 addresses the demonstration of innovative site characterization and/or drilling exploration technologies. The goal of this $\$ 100$ million FOA, which closed on $7 / 17 / 09$, is to reduce the high level of risk during early stages of geothermal project development by funding the validation of innovative exploration activities to locate undiscovered geothermal systems and increase the reliability of site characterization to prioritize target sites for energy production.

- Geothermal Energy Production from Low-Temperature Resources, Co-produced Fluids from Oil and Gas Wells, and Geopressured Resources. EISA Section 616 addresses geothermal energy production from oil and gas fields as well as the recovery and production of geopressured resources, while EPAct 2005 Section 931(a)(2)(C) includes authorization for geothermal energy production from low temperature geothermal resources. The goal of this $\$ 50$ million FOA, which closed on $7 / 17 / 09$, is to demonstrate the technical and economic feasibility of geothermal energy production from these nonconventional geothermal resources.

- Geothermal Data Development, Collection, and Maintenance. EPAct 2005 Section 931(a)(2)(C) includes authorization for continued data submission to the National Geothermal Data System (NGDS) created from Funding Opportunity Announcement DE-PS36-08GO98020. The goal is to develop, collect, and maintain data for all 50 states for the NGDS in order to make geothermal data available to the public and reduce the risk associated with initial stages of geothermal development. The $\$ 30$ Million FOA closed on 7/17/09.

- EGS Demonstration - $\$ 90$ million. ${ }^{12}$ This funding is for the further scientific exploration of the technologies and strategies necessary for achieving the potential of EGS.

- EGS Research and Development Analysis. This is an $\$ 80$ million FOA to support EGS technology development through cost-shared R\&D. The goal is to make EGS a major contributor to baseload generation.

IRS Clean Energy Renewable Bonds. Public entities are eligible to participate in Clean Renewable Energy Bonds (CREBs). These bond mechanisms were created by the 2005 Energy Tax Incentives Act and provide a tax credit to purchasers instead of an interest payment from the public issuing entity. ${ }^{13}$ In the two previous rounds of issuance, no CREBs have been issued by governments looking to use the mechanism for geothermal projects (Cory et al. 2008). The bonds are primarily used for solar projects, but the reason for a lack of geothermal projects is unknown: it is possible that there is a lack of knowledge of the program in the geothermal community, that larger scale projects are eligible for the program but are required to bring a large percentage of other financing in order to successfully participate, or that there is a lack of projects with enough interested bond purchasers, among other reasons.

\footnotetext{
${ }^{12}$ http://www07.grants.gov/search/announce.do;jsessionid=qJLWKzFTtsXJ0kMhx5gDhPH6DGRVjGzHxbfPyvr26j 9rK84n1NNw!1656926990

${ }^{13}$ Section 1303 of the Energy Tax Incentives Act of 2005, Pub. L. No. 109-58, 119 Stat. 594 (2005) (the "2005 Act") added section 54 to the Internal Revenue Code.
} 


\subsubsection{State Barrier-Reduction Policies}

State $R \& D$ Programs: Because the scale of research and development is typically large and requires extensive investment, states are generally not well positioned to implement $R \& D$ programs without federal support. California is the only state with a state-funded R\&D program for geothermal. Using funds from leasing royalties, California makes R\&D funds available to qualifying applicants under the Geothermal Resources Development Account (GRDA) (CEC 2008). From its inception in 1980, the program has funded at least four geothermal projects, as well as a number of direct-use projects (CEC 2008).

State Renewable Portfolio Standards: State renewable portfolio standards (RPS) policies have been cited by developers as a significant driver for geothermal development, as they encourage utilities to sign power purchase agreements for geothermal power (Fleischmann 2007, See Appendix 2) and serve to reduce the uncertainty that power available will be purchased. Eight of the thirteen states with planned geothermal plants have passed renewable portfolio standards. Only New Mexico's RPS has a set-aside for geothermal (together with biomass for a $10 \%$ total starting in 2011), in an effort made by the legislature to ensure a diversified energy portfolio resulting from the RPS. To encourage and to attribute higher value to geothermal development, New Mexico's RPS has a two-fold multiplier for geothermal energy. This multiplier strategy within the RPS mechanism is most commonly used for solar technologies that are rarely the least-cost option. Table 3 compares the current state of the market and the RPS targets in states with current or planned geothermal development (in these cases, hydrothermal, due to the commercial stage of the technology).

Table 3. RPS Targets and Installed and Planned Capacity in States with Hydrothermal Geothermal Development

\begin{tabular}{|c|c|c|c|c|}
\hline State & $\begin{array}{c}\text { Installed } \\
\text { Hydrothermal } \\
\text { Capacity (MWe) }\end{array}$ & $\begin{array}{l}\text { Hydrothermal } \\
\text { Capacity in } \\
\text { Development } \\
\text { (MWe) (Phase 1- } \\
\text { 4, high estimate) }\end{array}$ & $\begin{array}{c}\text { Current RPS } \\
\text { Target }\end{array}$ & $\begin{array}{l}\text { Year of First } \\
\text { Requirement }\end{array}$ \\
\hline California & 2605.3 & 1365.6 & $20 \%$ by 2010 & 2003 \\
\hline Nevada & 333 & 3297.4 & $25 \%$ by $2025^{*}$ & 2006 \\
\hline Utah & 50 & 194 & \multicolumn{2}{|c|}{ No RPS } \\
\hline Hawaii & 35 & 8 & $40 \%$ by $2030^{*}$ & 2010 \\
\hline Idaho & 15.8 & 326 & \multicolumn{2}{|c|}{ No RPS } \\
\hline Alaska & 0.68 & 100 & \multicolumn{2}{|c|}{ No RPS } \\
\hline Wyoming & 0.25 & 0.2 & \multicolumn{2}{|c|}{ No RPS } \\
\hline New Mexico & 0.24 & 10 & $20 \%$ by $2020^{* *}$ & 2002 \\
\hline Washington & 0 & $\begin{array}{c}\text { Undefined (1 } \\
\text { project) }\end{array}$ & $15 \%$ by 2020 & 2012 \\
\hline Oregon & 0 & 318.4 & $25 \%$ by 2025 & 2011 \\
\hline Arizona & 0 & 20 & $15 \%$ by 2025 & 1999 \\
\hline Colorado & 0 & 10 & $20 \%$ by 2020 & 2007 \\
\hline Florida & 0 & 1 & \multicolumn{2}{|c|}{ No RPS } \\
\hline \multicolumn{5}{|c|}{$\begin{array}{l}\text { *recently updated policy } \\
* * \text { for IOUs. } 10 \% \text { by } 2020 \text { for rural electric cooperatives. Policy contains a geothermal and biomass set } \\
\text { aside of } 10 \% \text { of the total requirement beginning in } 2011 . \\
\text { Source: GEA } 2009 \text {, Wiser and Barbose } 2008 \text {, DSIRE } 2009 \text {. }\end{array}$} \\
\hline
\end{tabular}


Despite developers citing RPS as market drivers for geothermal, there is currently no correlation between states with RPS and increased geothermal development. Since geothermal projects require multiple years from planning to implementation, RPS policies must be in place for multiple years to have an effect, possibly explaining the lack of correlation between policy and capacity growth (see Doris et al Forthcoming) for more information on connecting policy with capacity and generation of renewable resources). States with ambitious RPS targets (like California and Nevada) seem to have more geothermal power plants in development, although this analysis did not examine the relationship between a higher level of geothermal resources and the existence of an RPS that strongly encourages geothermal development.

\section{Other State Policies (Ownership, Unitization, and Regulatory Permitting):}

State policy relating to geothermal resources for electricity production varies by state and is not well categorized or published in aggregate. Two particular challenges to geothermal development would be alleviated by categorized and streamlined access to information including: (1) ownership of the resources and (2) potential or requirements for unitization of state and private land. The impact of these policy variations across state lines may be a barrier to geothermal development, so further research and better understanding of the laws and structures (such as through the ARRA data system described previously) could be of high value to developing geothermal resources.

Ownership of the geothermal resources can be ownership of the surface rights (e.g., Nevada Revised Statutes 534A.050, Oregon Revised Statutes Section 522.035, Revised Code of Washington Section 78.60.040), the mineral rights (e.g., California), or neither (e.g., Colorado Revised Statutes 37-90.5-104) (Fish and Heaps 2009). Lack of resource ownership clarity can create barriers to development because it requires extensive due diligence and research, often extending the length of time of resource development, which, in turn, can create challenges to securing project financing. While uniformity of ownership is not necessary, a clear understanding of state ownership rights and processes could reduce this barrier to development.

In addition to ownership, the lack of understanding of geothermal resource unitization rules and regulations may be a barrier to efficient development of geothermal resources. Unitization of geothermal resources allows multiple landowners or leaseholders to pool the geothermal resource to optimize the expenses associated with resource access (e.g., equipment) and distribute the energy benefits, thereby more efficiently using the resource. While many states (e.g., Utah Administrative Code R850-27) clarify the ownership and unitization rights of leaseholders on state lands, unitization of private resources is less clearly outlined. State rules vary regarding private land unitization, from the state actively regulating the resource (e.g., Arizona Revised Statutes $\S 27-664$ Cooperative development agreements; unitization) to the state taking an interest when the resource is deemed in the public interest (e.g., Oregon Revised Statutes 522.405) to states being silent on private land unitization. Lack of state guidelines for unitization could be reducing the incentive for landowners to optimize the geothermal resources available.

Regulatory permitting, too, can be a hindrance to geothermal development (Hance 2005). Different, and in many cases, multiple state regulatory bodies are responsible for permitting geothermal wells; the process is not always straightforward. Many states have regulations for 
permitting water wells and oil/gas wells, but not for geothermal wells specifically (Fish and Heaps 2009). This lack of clarity can cause delays in permit approvals and in project development, increasing geothermal capital costs due to increased financing costs.

Ownership, unitization, and regulatory permitting are only three potential contextual issues with broad impacts on the development of geothermal resources. Increased clarity of the rules and interests of states is a first step in gaining better understanding of the process that needs to be undertaken by developers in each state. A broad review of the potential legislative and regulatory barriers to development could identify further areas where regulatory and legislative clarity at the state level could contribute to the reduction of barriers to resource development.

\subsubsection{State Financial Incentives}

State Tax Incentives: Fifteen states offer one or more tax incentive(s) that can be applied to geothermal development. ${ }^{14}$ Table 4 describes the current level of these incentives and compares the incentive availability with the amount of installed and planned capacity in the state. There is currently no identifiable, direct relationship between installed capacity and current tax incentives, regardless of the amount of time the tax credit has been in place. This may be because of (1) the inadequacy of incentives to spur development in the state, as a result of other regulatory and siting barriers, (2) the relatively short time state incentives have been in place, (3) a mismatching of resource and incentive availability, or (4) a lack of focus on geothermal resources as a potential technology to apply for the incentive.

A critical aspect of state tax incentives is that they apply to commercially viable or near commercially viable technologies, not technologically emerging ones. This is particularly important in the case of geothermal technologies due to the emerging nature of EGS technology. While the current incentives may not be highly effective for maximizing the already-commercial hydrothermal technologies, well designed and funded state incentives may play a role in the development of markets for EGS when that technology is near commercial, as well-designed tax incentives targeting commercial technologies have been shown to have an impact on utility scale renewable energy development (Lantz and Doris, forthcoming).

\footnotetext{
${ }^{14}$ Tax incentives come in four primary types: property, sales, investment, and production. Each type targets different points of the technology delivery cycle and has strengths and weaknesses. For a full discussion of tax incentives for renewable energy development, see Brown and Busche 2008 and Lantz and Doris, forthcoming.
} 


\begin{tabular}{|c|c|c|c|c|c|c|}
\hline & $\begin{array}{l}\text { Available Tax } \\
\text { Incentives }\end{array}$ & Value & $\begin{array}{c}\text { Date } \\
\text { Effective }\end{array}$ & $\begin{array}{l}\text { Expiration } \\
\text { Date }\end{array}$ & $\begin{array}{l}\text { Installed } \\
\text { Capacity } \\
\text { (MW) }\end{array}$ & $\begin{array}{c}\text { Hydrothermal } \\
\text { Capacity in } \\
\text { Development } \\
\text { (MW) (Phase } \\
\text { 1-4, high } \\
\text { estimate) }\end{array}$ \\
\hline \multirow{3}{*}{ NV } & Sales Tax Exemption & Varies & $7 / 2009$ & $6 / 2049$ & \multirow{3}{*}{333} & \multirow{3}{*}{3297.4} \\
\hline & $\begin{array}{l}\text { Local Option: Property } \\
\text { Tax Financing } \\
\text { Authorization }\end{array}$ & Varies & $5 / 2009$ & None & & \\
\hline & $\begin{array}{c}\text { Property Tax } \\
\text { Exemption }\end{array}$ & $100 \%$ & 7/1/1983 & None & & \\
\hline \multirow[b]{2}{*}{ UT } & Sales Tax Exemption & $100 \%$ & $7 / 1 / 2004$ & $6 / 30 / 2019$ & \multirow[b]{2}{*}{50} & \multirow[b]{2}{*}{194} \\
\hline & Production Tax Credit & $\begin{array}{l}\$ 0.0035 / \mathrm{kWh} \\
\text { for } 4 \text { years }\end{array}$ & $1 / 1 / 2001$ & $\begin{array}{c}\text { Evaluated } \\
\text { on or after } \\
2012\end{array}$ & & \\
\hline $\mathrm{HI}$ & $\begin{array}{l}\text { High Tech Business } \\
\text { Investment Tax Credit }\end{array}$ & $100 \%$ & $7 / 1 / 2001$ & $12 / 31 / 2010$ & 35 & 8 \\
\hline \multirow[b]{2}{*}{ ID } & Sales Tax Exemption & $100 \%$ & $4 / 12 / 05$ & $7 / 1 / 2011$ & \multirow[b]{2}{*}{15.8} & \multirow[b]{2}{*}{326} \\
\hline & Property tax exemption & $\begin{array}{c}100 \% \\
\text { (geothermal } \\
\text { producers } \\
\text { must pay a tax } \\
\text { of } 3 \% \text { of gross } \\
\text { energy } \\
\text { earnings) } \\
\end{array}$ & $1 / 1 / 2008$ & None & & \\
\hline WY & Sales Tax Exemption & $100 \%$ & 7/1/2003 & 6/30/2012 & 0.25 & 0.2 \\
\hline \multirow[t]{2}{*}{ NM } & $\begin{array}{l}\text { Local Option: Property } \\
\text { Tax Financing } \\
\text { Authority }\end{array}$ & Varies & 7/1/2009 & none & \multirow[t]{2}{*}{0.24} & \multirow{2}{*}{10} \\
\hline & $\begin{array}{l}\text { Product Manufacturers } \\
\text { Tax Credit }\end{array}$ & $\begin{array}{l}5 \% \text { of qualified } \\
\text { expenditures }\end{array}$ & 7/1/2006 & None & & \\
\hline \multirow{2}{*}{ OR } & $\begin{array}{l}\text { Property Tax } \\
\text { Exemption }\end{array}$ & $100 \%$ & 1/1/1976 & $7 / 1 / 2012$ & \multirow{2}{*}{0} & \multirow{2}{*}{318.4} \\
\hline & Investment Tax Credit & $\begin{array}{c}50 \% \text { of eligible } \\
\text { costs (up to } \\
\$ 10 \mathrm{M} \text { ) }\end{array}$ & $1 / 1 / 2007$ & $1 / 1 / 2016$ & & \\
\hline$A Z$ & $\begin{array}{l}\text { Property Tax } \\
\text { Exemption }\end{array}$ & $100 \%$ & $6 / 2009$ & None & 0 & 20 \\
\hline \multirow[b]{2}{*}{$\mathrm{CO}$} & $\begin{array}{c}\text { Sales Tax and } \\
\text { Property Tax } \\
\text { exemptions: Local } \\
\text { option to implement. }\end{array}$ & $\begin{array}{l}\text { Varies by } \\
\text { district }\end{array}$ & 8/3/2007 & None & \multirow[b]{2}{*}{0} & \multirow[b]{2}{*}{10} \\
\hline & $\begin{array}{l}\text { Property Tax } \\
\text { Assessment }\end{array}$ & $\begin{array}{c}\text { Varies, rate set } \\
\text { annually by } \\
\text { Division of } \\
\text { Property } \\
\text { Taxation } \\
\end{array}$ & $1 / 1 / 2001$ & None & & \\
\hline
\end{tabular}




\begin{tabular}{|c|c|c|c|c|c|c|}
\hline $\mathrm{FL}$ & Production Tax Credit & $\begin{array}{l}\$ 0.01 / \mathrm{kWh} \\
\text { (up to } \$ 5 \mathrm{M} \text { ) }\end{array}$ & $1 / 1 / 2007$ & $6 / 30 / 2010$ & 0 & 1 \\
\hline IN & $\begin{array}{l}\text { Property Tax } \\
\text { Exemption }\end{array}$ & $100 \%$ & 1/1/1975 & None & 0 & 0 \\
\hline KS & $\begin{array}{l}\text { Property Tax } \\
\text { Exemption }\end{array}$ & $100 \%$ & 1/1/1999 & None & 0 & 0 \\
\hline MD & Production Tax Credit & $\begin{array}{l}\$ 0.0085 / \mathrm{kWh} \\
\text { for } 10 \text { years } \\
\text { (up to } \$ 2.5 \mathrm{M} \text { ) }\end{array}$ & $7 / 1 / 2000$ & $12 / 31 / 2010$ & 0 & 0 \\
\hline MT & Investment Tax Credit & $35 \%$ & $1 / 1 / 2002$ & None & 0 & 0 \\
\hline \multirow[b]{2}{*}{ ND } & Property tax exemption & $100 \%$ & $7 / 1 / 2007$ & None & \multirow[b]{2}{*}{0} & \multirow[b]{2}{*}{0} \\
\hline & Investment tax credit & $\begin{array}{c}15 \% \text { ( } 3 \% \text { for } 5 \\
\text { years) }\end{array}$ & $1 / 1 / 2001$ & $1 / 1 / 2011$ & & \\
\hline OK & Production Tax Credit & $\begin{array}{l}\$ 0.0025 / \mathrm{kWh}- \\
\$ 0.0075 / \mathrm{kWh} \\
\text { for } 10 \text { years }\end{array}$ & $1 / 1 / 2003$ & $12 / 31 / 2015$ & 0 & 0 \\
\hline PA & Production Tax Credit & $\begin{array}{l}15 \% \text { project } \\
\text { costs }\end{array}$ & $7 / 9 / 2008$ & $12 / 31 / 2016$ & 0 & 0 \\
\hline SD & $\begin{array}{c}\text { Property Tax } \\
\text { Exemption }\end{array}$ & $50 \%$ & $1 / 1 / 1975$ & None & 0 & 0 \\
\hline VT & $\begin{array}{l}\text { Local Option: Property } \\
\text { Tax Financing } \\
\text { Authorization }\end{array}$ & Varies & $5 / 2009$ & None & 0 & 0 \\
\hline
\end{tabular}

The table shows that a handful of states - including Montana, North Dakota, South Dakota, Indiana, Kansas, and Maryland - offer tax credits for geothermal but have not experienced any market development in electricity production from geothermal. Note that some of these incentives, considering relatively small scale and scope, are likely to target nonelectricity generation technologies, such as direct-use geothermal and ground source heat pumps. As a result, there is potential that the impact of the programs is manifested in those markets, and the impact on geothermal capacity development is masked. The western states with tax incentives (e.g., Montana, North Dakota, Indiana, and Kansas) have some limited resource available as well as a tax incentive, and little to no development. This indicates inappropriately sized or targeted incentives, and, based on the small size of incentives, is likely to be a reflection of a focus on nonelectricity generation technologies. Other barriers, such as regulatory and land-use barriers may be larger opportunities for policy to have an impact on geothermal development in these locations. In California, for instance, electric capacity has developed in the presence of other incentives, but without a tax incentive.

Non-Tax-Related State Financial Incentives: Sixteen states and the District of Columbia have other financial incentives for geothermal power including grants, loans, and loan guarantees. Table 5 shows the availability of "geothermal" incentives in states compared with the amount of operating or planned geothermal capacity. There is not a significant correlation between these incentives and higher installed hydrothermal capacity in a state. As with tax incentives, these incentives are likely so broad in definition that the benefit to geothermal electricity production decreases. Even when appropriately applied to geothermal in scale and scope, effectiveness of the incentive changes with changes and advances in technology, and that may be critical in the case of geothermal technology development. 
It is unknown whether current or planned plants have received grants or loans under these state policies, but evidence indicates that the largest projects have not taken advantage of these incentives. For example, the Alaska Energy Authority's grant program was established after the Chena Hot Springs plant went in the ground (GEA 2008a). Additionally, Idaho's first commercial geothermal plant was a qualifying facility (QF) under PURPA (Fleischmann 2006a) and the Idaho Renewable Energy Bond program established in 2005 excludes PURPA QFs.

\begin{tabular}{|c|c|c|c|c|c|}
\hline & Incentive & $\begin{array}{c}\text { Year Enacted } \\
\text { (or inclusive } \\
\text { of } \\
\text { geothermal) }\end{array}$ & Details & $\begin{array}{l}\text { Installed } \\
\text { Capacity } \\
\text { (MW) }\end{array}$ & $\begin{array}{l}\text { Hydrothermal } \\
\text { Capacity in } \\
\text { Development } \\
\text { (MW) (Phase 1-4, } \\
\text { high estimate) }\end{array}$ \\
\hline CA & $\begin{array}{l}\text { Public Benefits } \\
\text { Fund }\end{array}$ & 1998 & $\begin{array}{l}\text { Renewables: 2002-2006: } \\
\text { \$135 M annually; 2007: \$135 } \\
\text { M; 2008-2011: \$65.5 M } \\
\text { annually }\end{array}$ & 2605.3 & 1365.6 \\
\hline ID & $\begin{array}{l}\text { State Bond } \\
\text { Program }\end{array}$ & 2005 & $\begin{array}{l}\text { Bonds extended to both } \\
\text { facilities qualifying and not } \\
\text { qualifying under PURPA }\end{array}$ & 15.8 & 326 \\
\hline AK & $\begin{array}{l}\text { Alaska Energy } \\
\text { Authority- } \\
\text { Renewable } \\
\text { Energy Grant } \\
\text { Program }\end{array}$ & 2008 & $\begin{array}{l}\text { Program budget for FY } 2009 \\
\text { is } \$ 100 \mathrm{M}\end{array}$ & 0.68 & 100 \\
\hline \multirow[t]{2}{*}{ OR } & $\begin{array}{l}\text { Oregon } \\
\text { Energy Trust- } \\
\text { Public Benefits } \\
\text { Fund And } \\
\text { Grant Program }\end{array}$ & 2002 & $\begin{array}{l}\text { General fund for renewables } \\
\text { is } \$ 12 \mathrm{M} \text { annually through } \\
2025 \text {. Grants for } \\
\text { hydroelectric, geothermal } \\
\text { electric, wave energy, and } \\
\text { fuel cells are provided under } \\
\text { the public benefits fund. The } \\
\text { program budget is } \sim \$ 2 \mathrm{M} \\
\text { annually. }\end{array}$ & \multirow[t]{2}{*}{0} & \multirow[t]{2}{*}{318.4} \\
\hline & $\begin{array}{l}\text { Small-Scale } \\
\text { Energy Loan } \\
\text { Program }\end{array}$ & 1980 & $\begin{array}{l}\text { Low-interest loans for smaller } \\
\text { projects, generally awarded } \\
\text { between } \$ 20,000 \text { to } \$ 20 \mathrm{M}\end{array}$ & & \\
\hline $\mathrm{FL}$ & $\begin{array}{l}\text { Renewable } \\
\text { Energy } \\
\text { Technologies } \\
\text { Grants } \\
\text { Program }\end{array}$ & 2006 & $\begin{array}{l}\text { Matching grants for } \\
\text { demonstration, } \\
\text { commercialization, and R\&D } \\
\text { projects. Program budget is } \\
\$ 15 \text { M for FY 2006-07; } \$ 12.5 \\
\text { M for FY 2007-08; } \$ 15 \text { M for } \\
\text { FY 2008-09 }\end{array}$ & 0 & 1 \\
\hline $\mathrm{DE}$ & R\&D Grants & 2003 & $\begin{array}{l}\text { Award equals } 35 \% \text { cost of } \\
\text { qualifying projects up to } \\
\$ 250,000 \text { per project. The } \\
\text { program budget is } \$ 288,000 \\
\text { annually. }\end{array}$ & 0 & 0 \\
\hline $\mathrm{DC}$ & $\begin{array}{l}\text { Renewable } \\
\text { Energy } \\
\text { Demonstration } \\
\text { Project (R\&D } \\
\text { Grants) } \\
\end{array}$ & 2006 & $\begin{array}{l}\text { Four rounds of grants have } \\
\text { been awarded. There may be } \\
\text { additional funds available for } \\
2009 \text {. }\end{array}$ & 0 & 0 \\
\hline
\end{tabular}




\begin{tabular}{|c|c|c|c|c|c|}
\hline IL & $\begin{array}{l}\text { Public Benefits } \\
\text { Fund }\end{array}$ & 1997 & $\begin{array}{l}\text { The renewable energy resource } \\
\text { trust fund is funded by a } \\
\text { ratepayer surcharge that } \\
\text { supports grant and rebate } \\
\text { programs through the Illinois } \\
\text { Department of Commerce and } \\
\text { Economic Opportunity. The } \\
\text { fund is valued at approximately } \\
\$ 100 \text { M per year. }\end{array}$ & 0 & 0 \\
\hline MA & $\begin{array}{l}\text { Public Benefits } \\
\text { Fund }\end{array}$ & 1998 & $\begin{array}{l}\text { The Renewable Energy Trust is } \\
\text { funded by a ratepayer } \\
\text { surcharge that supports grant } \\
\text { and rebate programs through } \\
\text { the Massachusetts Technology } \\
\text { Collaborative. The fund is } \\
\text { valued at approximately } \$ 25 \mathrm{M} \\
\text { per year. }\end{array}$ & 0 & 0 \\
\hline ME & $\begin{array}{l}\text { Public benefits } \\
\text { fund- } \\
\text { Voluntary } \\
\text { Renewable } \\
\text { Resources } \\
\text { Grants }\end{array}$ & 2000 & $\begin{array}{l}\text { A voluntary public benefits fund } \\
\text { supports the R\&D Grant } \\
\text { program. As of July } 1,2007 \text { the } \\
\text { fund contained } \sim \$ 400,000 \text {. } \\
\text { Individual awards up to } \$ 50,000 \\
\text { for small-scale demonstration } \\
\text { projects. }\end{array}$ & 0 & 0 \\
\hline MS & $\begin{array}{l}\text { Energy } \\
\text { Investment } \\
\text { Loan Program }\end{array}$ & 1989 & $\begin{array}{l}\text { Low-interest loan program ( } 3 \% \\
\text { below prime rate, } 7 \text {-year } \\
\text { payback). Amount ranging from } \\
\$ 15,000 \text { to } \$ 300,000 \text {. }\end{array}$ & 0 & 0 \\
\hline MT & $\begin{array}{l}\text { Public benefits } \\
\text { fund }\end{array}$ & 1997 & $\begin{array}{l}\text { Fund is } \sim \$ 10 \mathrm{M} \text { annually. The } \\
\text { fund is set to expire at the end } \\
\text { of } 2009 \text {. }\end{array}$ & 0 & 0 \\
\hline NE & $\begin{array}{l}\text { Dollar and } \\
\text { Energy } \\
\text { Savings Loans }\end{array}$ & & $\begin{array}{l}\text { Low-interest loan program, } \\
\text { mainly for energy efficiency } \\
\text { improvements. Renewables are } \\
\text { eligible if included in a list of } \\
\text { "pre-qualified improvements" } \\
\text { with minimum efficiency } \\
\text { standards, or if the project will } \\
\text { have a reasonable payback } \\
\text { period. Loans range from } \\
\$ 75,000 \text { to } \$ 175,000 \text {. }\end{array}$ & 0 & 0 \\
\hline NJ & $\begin{array}{l}\text { Public Benefits } \\
\text { Fund }\end{array}$ & 1999 & $\begin{array}{l}\text { Total fund size for renewables } \\
\text { between } 2001 \text { and } 2008 \text { was } \\
\text { approximately } \$ 300 \mathrm{M} \text {. The } \\
\text { budget proposal for } 2009-2012 \\
\text { is roughly } \$ 243 \mathrm{M} \text { for } \\
\text { renewables. }\end{array}$ & 0 & 0 \\
\hline NY & $\begin{array}{l}\text { Public Benefits } \\
\text { Fund }\end{array}$ & 1996 & $\begin{array}{l}\text { The total fund is equal to } \$ 1.87 \\
\mathrm{~B}(1998-2011) \text {, for the period } \\
2006 \text { to } 2011 \$ 182 \mathrm{M} \text { is } \\
\text { allocated to } R \& D \text { (including } \\
\text { renewables). }\end{array}$ & 0 & 0 \\
\hline $\mathrm{OH}$ & $\begin{array}{l}\text { Public Benefits } \\
\text { Fund }\end{array}$ & 1999 & $\begin{array}{l}\text { This is funded by a ratepayer } \\
\text { surcharge that supports grant } \\
\text { and rebate programs through } \\
\text { the Advanced Energy Program. } \\
\text { The fund is valued at } \\
\text { approximately } \$ 5 \mathrm{M} \text { per year. }\end{array}$ & 0 & 0 \\
\hline
\end{tabular}




\begin{tabular}{|c|c|c|c|c|c|}
\hline \multirow[b]{2}{*}{$\mathrm{RI}$} & $\begin{array}{l}\text { Renewable } \\
\text { Energy Fund } \\
\text { Loans }\end{array}$ & 2008 & $\begin{array}{l}\text { For projects that directly benefit } \\
\text { the state of Rhode Island. Loan } \\
\text { terms vary depending on } \\
\text { project type. }\end{array}$ & \multirow[b]{2}{*}{0} & \multirow[b]{2}{*}{0} \\
\hline & $\begin{array}{l}\text { Public Benefits } \\
\text { Fund }\end{array}$ & 1996 & $\begin{array}{l}\text { Since } 2002 \text { there has been a } \\
\text { separate surcharge for } \\
\text { renewables. The annual budget } \\
\text { for renewables between } 2003 \\
\text { and } 2013 \text { is } \sim \$ 2.4 \mathrm{M} \text {. A } 2008 \\
\text { amendment has allocated half } \\
\text { of that fund for municipal } \\
\text { renewable projects. }\end{array}$ & & \\
\hline TN & $\begin{array}{l}\text { Small } \\
\text { Business } \\
\text { Energy Loan } \\
\text { program }\end{array}$ & 1987 & $\begin{array}{l}\text { No or low-interest loans for } \\
\text { small businesses up to } \\
\$ 300,000 \text {. }\end{array}$ & 0 & 0 \\
\hline WI & $\begin{array}{l}\text { Energy } \\
\text { Independence } \\
\text { Fund Grant } \\
\text { and Loan } \\
\text { Program }\end{array}$ & 2008 & $\begin{array}{l}\text { Cost-sharing grants (R\&D) and } \\
\text { low-interest loans that cover a } \\
\text { maximum of } 25 \% \text { of the project } \\
\text { cost. The fund is a } 10 \text {-year, } \\
\$ 150 \mathrm{M} \text { initiative. Typical } \\
\text { awards range from } \$ 100,000 \text { to } \\
\$ 500,000\end{array}$ & 0 & 0 \\
\hline VT & $\begin{array}{l}\text { Public Benefit } \\
\text { Fund }\end{array}$ & 2009 & $\begin{array}{l}\text { The Clean Energy } \\
\text { Development Fund is funded by } \\
\text { Entergy in an agreement } \\
\text { pertaining to a Vermont Nuclear } \\
\text { Plant, and promotes the } \\
\text { deployment of cost effective } \\
\text { renewable energy technologies. } \\
\text { The program is funded annually } \\
\text { between } \$ 6-7.2 \text { million } \\
\text { annually. }\end{array}$ & 0 & 0 \\
\hline \multicolumn{6}{|c|}{$\begin{array}{l}\text { DSIRE Web site search } \\
\text { page:http://dsireusa.org/searchby/searchtechnology.cfm?\&CurrentPagelD=2\&EE=0\&RE=1. Source: GEA } \\
2009 \text { and DSIRE } 2009 \text {. } \\
\text { Note: Incentives in this table may also apply to ground source heat pumps and direct-use technologies as } \\
\text { well as electricity production. }\end{array}$} \\
\hline
\end{tabular}

Despite the lack of correlation between individual state policies, developers seeking out RPS and other policies indicate that policies are of some value to developers looking for energy investments (Fleischmann 2007). The previously described contextual factors (including electricity prices and volatility, resource availability, regulatory environment, amount of previous characterization, exploration, and drilling has occurred) are important, but are difficult to quantify in the literature. Research into their relative impacts is just getting under way (e.g., Brown and Busche 2008, Doris et al. forthcoming).

\subsection{Chapter Summary}

To summarize the review, the historical and current policy picture reflects a piecemeal approach to geothermal resource development, and often reflects geothermal development as a part of collective renewables policies, without geothermal-electric specific policies in place. Moreover, multiple technologies that involve using the earth are sometimes defined as geothermal in the policy language, despite the differences in public policy needs of the technology. These challenges result in difficulties in evaluating policy impacts on electricity from geothermal 
resources, because electricity production technology is then in competition with other renewable technologies that may be further along in development or better understood by the public, and are therefore chosen.

The findings are inconclusive as to the direct impact of specific policies on electricity production from geothermal development, although there appears to be a connection between federal policies and historical geothermal development. Finally, there is empirical and qualitative evidence that the impact of state-level policies are funding-limited instead, resulting in a lack of private sector investment related to the uncertainty of actually receiving the incentive before the state funding is exhausted. That is, incentives for central generation geothermal need to be sized appropriately to the amount of investment needed larger scale, and often state policies are too limited in their ability to fund incentives to have a large impact on project costs.

These two results - lack of a focus on geothermal-electric development specifically and lack of adequate resources to support the specific technology - form the basis for the final section of this report, which identifies options for filling the gaps in policy development through additional measures and innovative mechanisms (e.g., feed-in tariffs) that may have a larger impact than the current suite of policies. 


\section{Chapter 3. Moving Forward: Geothermal Policy Options Overview}

This section identifies the primary gaps in current geothermal development policies and use current and innovative policies to fill those gaps to optimize development. As described in the introduction to Chapter 2, the following policy attributes may be the most effective at correcting market failures that apply to geothermal resources:

- Long-term (multi-year) upfront cost defrayment to reduce risk and provide support until power production begins

- Targeted policies in accordance with resource availability

- Appropriately sized incentives to meet the needs of the full range or some portion of the range between 250 kilowatts $(\mathrm{kW})$ to multi-megawatt facilities

- Appropriate recognition of the environmental and load benefits of baseload renewable energy generation.

The findings indicate that there are several gaps in current policies where they could be strengthened to increase their impact, including increasing funding and policy consistency.

\subsection{Gaps and Opportunities in Current Policy Structure}

Current in-place policies have not triggered large-scale market penetration for geothermal relative to the potential resource. Primary observations regarding geothermal policies are is that they do not focus on the geothermal market specifically, they do not present a cohesive slate of policies for optimizing development, and there is evidence that they are not appropriately funded or targeted for optimizing geothermal growth. Within this context, the primary gaps within the current slate of policies are:

\subsubsection{Geothermal-Specific Policies and In-Policy Carve Outs.}

Developing policies specifically for geothermal electricity production would allow for targeting of the specific needs of the technologies that take advantage of geothermal resource, rather than for a suite of technologies with variant needs. Increasing the specificity of the policies can lead to higher impact policies. In addition, for policies that can target large-scale capacity building, such as RPS, the use of targeted geothermal development has been limited. Solar technologies have seen success in this strategy, as it increases the value for the more expensive technology and can create investor certainty to encourage development. The one state that has done this for geothermal is New Mexico, and while outcomes are yet to be determined, it appears to be increasing interest in geothermal development in the state.

\subsubsection{Improvements in Current Policies}

In addition to implementing new policies, aspects of current policies can be improved to strengthen their impact. These aspects include:

Consistency. The growth pattern of emerging technologies can depend on policy funding levels and consistency of policies over time. Geothermal facilities require multiple years to plan and 
build, so the reduction of risk to investors and builders needs to be secure throughout the process, or the level of risk will become a barrier to development. Policies that target geothermal need to ensure consistency by being in place for at least $8-10$ years.

Adequate Funding. Rapidly sold-out financial incentives and those designed for small distributed generation are not adequate to trigger geothermal development. To solve this challenge, improving policy design for geothermal electricity-targeted policies, increasing the level of investment in the incentives at the state level, or increasing federal investment in R\&D to lower the cost of technologies (thereby making the state incentives more effective at lowering the price) are options.

Appropriate Audience. Large-scale geothermal projects involve stakeholders from a variety of sectors, including utilities, land-owners, environmentalists, policy makers from multiple jurisdictions, developers, and investors. Current policies may target one or more of these, but do not address the multiple needs of stakeholders together. Doing so is challenging, but can be done through coordinated policy development and implementation that targets both barrier reduction and financial incentives, as well as policy stability over time.

State-Level Permitting Alterations to Remove Institutional Barriers. While this report addresses policy barriers in general, there are several potential improvements to current policies that could address institutional barriers. For example, because one of the largest barriers to geothermal resource development is ensuring financing and policies throughout the exploration process, it would be helpful for permitting procedures to require all future wells (water, gas, oil, geothermal, research, etc.) to require submission of well data (depths, geology, flow rates, test results, well logs, construction, etc.) to the state in order to remain current. The data could be fed into a data center that could be publically accessible and relay information in a streamlined fashion to developers of future projects. The DOE Geothermal Technologies Program is currently funding the development of a data system to house such information.

\subsection{Innovative Policies and Programs}

In addition to strengthening and expanding the current suite of policies, there is a role for emerging policies to play an increasing role in development if those policies are designed to optimize benefits of geothermal. Feed-in tariffs and policies that prepare the market through agency coordination are such policies that could have a large impact on geothermal development. In the past, agency coordination has played a major role in successful projects (Fleischman 2007). Subsequently, an innovative program that draws together agencies in coordination on projects is also described.

These policy and program strategies are suggested as potential reforming improvements to the current policy patchwork. They require further thought and examination to ensure geothermal resources are maximized through their implementation, but this first look provides an overview. 


\subsubsection{Feed-In Tariffs (FIT)}

A feed-in tariff (FIT) is a fixed-price payment for renewable energy generation. FIT policies typically require utilities to purchase electricity from qualified renewable energy generators at a guaranteed price for a guaranteed period of time. This guaranteed payment is often coupled with guaranteed grid access. These payments can be differentiated according to the technology type, project size, quality of the resource, and a number of other project variables (Couture et al 2008).

Feed-in tariffs have had a major impact on the large-scale development of renewable resources internationally. They have been used extensively in Europe for nearly two decades, which has created two of the largest markets for wind in the world. FITs have also driven investment in geothermal in Europe, where resource potential is not as strong as in the United States.

As a policy option, FITs have several advantages. FITs provide investor security, because the policy provides a guaranteed revenue stream and stable, long-term contracts. FIT policies are put into place over a long period of time to provide policy stability and reduce uncertainty. Yet, FITs are flexible in that policymakers can adjust payment levels to accurately reflect technology costs and avoid overpayment. To drive innovation and cost-reduction over time, FIT policies have built-in payment level revisions.

The disadvantage of FIT application to geothermal projects is that the mechanism does not address the regulatory and R\&D issues associated with geothermal. These include leasing barriers that exist for geothermal and exploration and technology development assistance. Due to the specificity of the electric markets, the appropriate implementers of FIT policies are at the state level (Couture et al 2008). Such policies can complement or replace state RPS policies in order to reach renewable energy targets established by the states.

\subsubsection{Agency Coordination}

Geothermal resources with central-generation capacity potential are often located on public lands that are at the intersection of multiple agency jurisdictions. In the past, agency coordination has played a major role in successful projects (Fleischman 2007). Policies that encourage or direct public agency coordination and public private partnership can create the environment for increased development of geothermal resources. In 2007, the BLM and USFS came together at the direction of the Energy Policy Act of 2005 to identify available land for hydrothermal resources and streamline the permitting process leasing that land to private entities for development. Continued public agency coordination in the identification and distribution of best practices for geothermal resource development is critical for the full range of technologies from hydrothermal to EGS. The BLM/USFS coordination resulting in the PEIS primarily directed toward hydrothermal technologies is an example of the beneficial impacts of coordination.

In addition to public partnerships, public-private partnerships are also highly effective in the development of central generation facilities such as those from geothermal (Fleischmann 2007, REN21). The large time and economic costs associated with site identification, drilling, fracturing, and, navigation through complex regulation are eased by networks of partnerships. These networks can be particularly useful for emerging technologies such as EGS because the cost sharing aspects of partnerships defrays risks. This strategy is being used in one of the DOE geothermal program's funding opportunity announcements to support the development of costshared EGS (DOE 2008). 


\section{Chapter 4. Conclusions and Next Steps}

According to the 2008 USGS/USFS Geothermal Resource Potential Study (PEIS), there is a significant amount of identified and undiscovered hydrothermal potential in the United States. The potential for EGS, when the technology is through the demonstration phase, is also expected to be extensive (MIT 2006). The role of policy is to drive development of these resources by furthering technology development, reducing barriers and risk, and bringing down the price of development. It is clear from the experience that drove hydrothermal development in the 1970s and 1980s that R\&D investment, public-private partnerships for the streamlining of permitting and project development, and consistent effective financial incentives are critical for success. Adapting policies to the needs of EGS as it develops will be important as well.

Technology R\&D support is still critical for the geothermal industry, both for bringing down costs of developing areas of known and undiscovered hydrothermal potential and for advancing enhanced geothermal systems (EGS) technologies, an innovative generation method with large potential across the United States. There is significant potential for improvement in the areas of exploration and resource assessment and drilling. Despite recent actions of the PEIS, hydrothermal barriers still exist due to leasing and permitting constraints on federal lands, where much of the identified resources are located. Beyond barrier reduction, geothermal needs consistent support from both federal and state policies. State and federal policies should encourage utilities to enter long-term contracts with geothermal developers, because long-term power purchase agreements have historically made projects viable.

Ultimately, it is the confluence of policies, technology appropriateness, resource availability, financing mechanisms for appropriately timed risk reduction, and other context related factors that influence the development of actual geothermal resources for electricity. The current policy environment, while extensive, does not simultaneously repair the market failures inherent in geothermal development, and could be improved to better fill these gaps. Further analysis of the impacts of policies and incentives that target geothermal is needed so that states can choose appropriate mechanisms to reduce barriers and foster geothermal development.

At the federal level, R\&D investments in technology improvement, price reduction, resource assessment, and drilling assistance are needed.

At the state level, expanded analysis of the potential impact of RPS and feed-in-tariffs on geothermal resources would provide insight into geothermal-friendly policy design, and current policies could be augmented through improved definitions for geothermal and required data feedback mechanisms to streamline future developments.

Lastly, analysis needs to be conducted on appropriate stakeholder involvement, including the role of public-private partnerships, technology incubators, and local governments in supporting geothermal. 


\section{References}

Brown E., and S. Busche. 2008. "State of the States 2008: Renewable Energy Trends and The Role of Policy." NREL/TP-670-43021.

BLM (Bureau of Land Management). 2009. Geothermal Lease Sale Generates More than \$9M. Press Release. URL: http://www.blm.gov/wo/st/en/info/newsroom/2009/july/NR_0715_2009.html. Accessed August 4, 2009.

. 2008. Geothermal PEIS.

http://www.blm.gov/pgdata/etc/medialib/blm/wo/MINERALS REALTY AND_RES OURCE PROTECTION/energy/geothermal eis/final programmatic.Par.90935.File.dat ROD Geothermal 12-17-08.pdf. Accessed June 2009.

. 2007a. BLM Geothermal Lease Auction Signals New Trend in Renewable Energy. http://www.blm.gov/wo/st/en/info/newsroom/2007/august/NR 0708 04.html. Accessed September 2009.

. 2007b. Utah BLM Geothermal Lease Sale Nets Over \$3.5 Million http://www.blm.gov/ut/st/en/info/newsroom/2007/06/ 620_2007_html. Accessed September 2009.

CEC (California Energy Commission). 2008. "Geothermal Energy in California." http://www.energy.ca.gov/geothermal/ Accessed 6 January 2009.

CFR (Code of Federal Regulations). 2009. 43 CFR Part 3280. URL: http://law.justia.com/us/cfr/title43/43-2.1.1.3.54.1.html. Accessed July 30, 2009.

Couture T., Cory K., Williams E., and C. Kreycik. Forthcoming. "Feed-in Tariff Policy Design and Implementation: Best Practices Guide."

Cory, K, J. Coughlin, and C. Coggeshall. 2008. Solar Photovoltaic Financing: Deployment on Public Property by State and Local Governments. NREL/TP-670-43115. URL: http://www.nrel.gov/docs/fy08osti/43115.pdf

DOE (Department of Energy). 2008a. "Geothermal Timeline." http://www.eia.doe.gov/kids/history/timelines/geothermal.html Accessed 22 Oct 2008.

DOE (Department of Energy). 2008b. DOE Geothermal Technology Program News Releases. URL: http://www1.eere.energy.gov/geothermal/news detail.html?news id=12018. Accessed January 6, 2009.

DOI (Department of the Interior). 22 Oct 2008a. "Kempthorne Launches Initiative to Spur Geothermal Energy and Power Generation on Federal Lands." http://www.doi.gov/news/08_News_Releases/102208b.html Accessed 1 Nov 2008. 
.2008b. Record Geothermal Lease Sale Generates \$28 Million in Bids, press release, http://www.doi.gov/news/08_News_Releases/080808b.html

Doris, E., J. Mclaren, V. Healey, S. Hockett, and. Forthcoming. State of the States 2009: State Renewable Energy Development and the Role of Policy. NREL: Golden, Co

DSIRE. 2008. "State and Federal Incentives for Geothermal.” http://dsireusa.org/ Accessed 22 Oct 2008 .

Energy Information Agency. 1995. "Background Information and 1990 Baseline Data Initially Published in the Renewable Energy Annual 1995.” DOE/EIA-0603(95) http://www.eia.doe.gov/cneaf/solar.renewables/renewable.energy.annual/backgrnd/tablec on.htm

Energy Information Agency. 2008. “Geothermal capacity and generation, 1949-2007.” Annual Energy Review 2007.

Fish, J. and C. Heaps. 2009. Fundamentals of Geothermal Leasing. Stoel Rives LLP presentation. URL: www.stoel.com/webfiles/GeothermalLeasing_2009.ppt. Accessed July 20, 2009.

Fleischmann, D. 2006a. "Report: Geothermal Development Needs in Idaho.” Geothermal Energy Association.

Fleischmann, D. 2006b. "Report: Geothermal Development Needs in Nevada." Geothermal Energy Association.

Fleischmann, D. 2007. "EXECUTIVE SUMMARY - Geothermal Resource Development Needs in the Western United States Report." Geothermal Energy Association. URL: http://www.geoenergy.org/publications/reports/EXECUTIVE\%20SUMMARY\%20Geothermal\%20Reso urce\%20Development\%20Needs\%20Report\%20January\%202007.pdf

Gawell, K. 19 Apr 2007. "Testimony before the Subcommittee on Select Revenue Measures of the House Committee on Ways and Means." http://waysandmeans.house.gov/hearings.asp?formmode $=$ printfriendly\&id $=5794$ Accessed 5 Nov 2008.

GEA (Geothermal Energy Association). 2005. "Geothermal Leasing Old Law vs. New Law (HR 6): Highlights." And "Summary of the Geothermal Leasing Provisions of Title II of H.R. 6."

GEA (Geothermal Energy Association). 2009. US Geothermal Power Production and Development Update. March 2009. 
GEA (Geothermal Energy Association). 2008b. "U.S. Update on Geothermal Power Production and Development, August 2008."

Global Wind Energy Council. 2008. “Global Wind 2007 Report- Second Edition.”

GTP (DOE Geothermal Technologies Program. 2009. Multi-Year Program Plan. URL: http://www1.eere.energy.gov/geothermal/pdfs/gtp myrdd 2009-complete.pdf. Accessed September 2009.

Hance, C.N. 2005. Factors Affecting Costs of Geothermal Power Development. Geothermal Energy Association.

Kreycik, C., E. Doris, and L. Vimmerstedt. Forthcoming. A Framework for State Level Renewable Energy Market Potential Studies. NREL: Golden, Co.

Lantz E, and E. Doris. Forthcoming. State Clean Energy Policy Best Practices: Tax Incentives. NREL: Golden, Co.

Lantz, E. Forthcoming. State Clean Energy Policy Best Practices: Manufacturing Incentives. NREL: Golden, Co.

Levite, B., B. Pei, and A. Gino. 2005. "An analysis of federal loan guarantees for geothermal energy development." March.

Margolis, R. and D. Kammen. 1999. "Underinvestment: The energy technology and R\&D policy challenge”, Science, 285, 690 - 692.

Mastow, P., and A. Braff. 2008. Geothermal Site Acquisition and Early Development: Key Legal Issues and Emerging Strategies. Presentation. URL: www.geothermal.org/Powerpoint08/Monday/.../MostowMon08.ppt

Owens, Brandon. "An Economic Valuation of a Geothermal Production Tax Credit." NREL Technical Report. April 2002.

Renewable Energy World. "Geothermal Lease Auction Signals New Trend in U.S." 22 Aug 2007. http://www.renewableenergyworld.com/rea/news/story?id=49693

Senate Committee on Energy and Natural Resources. "The Energy Policy Act of 2005 Anniversary Report” 8 Aug 2006.

REN21. 2008. Website: Renewable Energy and Policy Network for the 21t Century Actions. URL: http://www.ren21.net/iap/commitment.asp?id=207. Accessed January 8, 2009.

MIT (Massachusetts Institute of Technology. 2006. The Future of Geothermal Energy: Impact of Enhanced Geothermal Systems on the Unites States in the $21^{\text {st }}$ Century. URL: 
http://geothermal.inel.gov/publications/future of geothermal energy.pdf. Accessed September 2009.

U.S. Department of Treasury. 2009. Guidance for the Treasury Office Grant from ARRA. URL: http://www.treas.gov/recovery/docs/guidance.pdf. Accessed July 30, 2009

USGS (U.S. Geological Survey). 2008. "Assessment of Moderate- and High-Temperature Geothermal Resources of the United States." Fact Sheet 2008-3082.

Walters, T., S. Savage, and J. Brown. 2006.USDA Section 9006 Program: Status and Benefits of Grant Awards in FY2003-FY2005. NREL: Golden, Co. URL: http://www.nrel.gov/docs/fy06osti/40465.pdf

Wiser R, Porter K, Grace R, Kappel C. 2003. "Evaluating State Renewable Portfolio Standards: A Focus on Geothermal Energy.” Prepared for National Geothermal Collaborative.

Wiser, R., and G. Barbose. 2008. "Renewables Portfolio Standards in the United States - A Status Report with Data Through 2007.” LBNL-154E. 


\section{Appendices}

\section{Appendix 1. Case Study: The Federal Production Tax Credit and Geothermal Development}

In 2005, the federal production tax credit was extended to geothermal power at a level of $1.9 \notin / \mathrm{kWh}$ for 10 years for geothermal plants that are placed in service before the expiration of the credit. At that time, the credit was made available through December 31, 2006. It has since been extended to December 31, 2008, and more recently to December 31, 2013.

Before the inclusion of geothermal in the technologies eligible to receive the PTC, analysis was conducted at NREL on the impact on cost of energy of an inflation-adjusted $1.8 \phi / \mathrm{kWh}$ PTC for geothermal. The impact of the PTC can result in a larger incentive than $1.8 \notin / \mathrm{kWh}$, because the policy also increases the certainty of project viability to investors, which can lead to improved financing conditions. The levelized-cost-of-energy (LCOE) metric reflects this potential additional benefit because it incorporates the improved financing opportunities over the lifetime of the project. LCOE for geothermal power plants financed through project and corporate financing was analyzed in the presence and absence of a 10-year production tax credit for the generation. The key findings were that a 10 -year PTC has the potential to reduce LCOE by $25 \%$ from 4.6 to $3.2 \notin / \mathrm{kWh}$ for a flash-steamed project under project financing, and by $44 \%$ from 5.0 to $2.8 \notin / \mathrm{kWh}$ for a similar project under corporate financing (Owens 2002).

Since its enactment, the PTC has aided developers in financing new geothermal projects in the western United States. In fact, some developers cite the PTC as the most important incentive currently available for geothermal energy (Fleischmann 2007). In Nevada, for example, 14 geothermal plants were developed between 1984 and 1992. When economics tightened for geothermal development in the 1990s (due to lower avoided-costs predictions leading to less favorable PURPA contracts), geothermal development in Nevada dropped off. No new geothermal power plants were developed in the state between 1992 and 2005, the year when the PTC first applied to geothermal energy. Drilling in the area had already been conducted, but the project did not go forward until the PTC was extended to geothermal (Fleischmann 2006b).

Because of the availability of the PTC, many new geothermal prospects are currently under development. However, federal legislation has followed a pattern of repeated expiration and short-term renewal of the PTC. Approaching expiration dates, there has been uncertainty over whether the PTC will be renewed. Furthermore, the PTC policy has strict placed-in-service requirements that prohibit developers from receiving any incentives if they miss the cut-off date. This short-term strategy has been detrimental to the renewables industry because costs of starting and stopping production and planning are high, and because developers and investors are discouraged from making long-term investments.

There has been a clear boom-bust cycle in wind power investment because of uncertainty over the PTC. The challenge is even more defined for the geothermal industry because geothermal plants have construction lead times of three or more years (Gawell 2007). The fact that placedin-service deadlines are so short poses extreme risk to developers. Since the development timeline is lengthy, geothermal developers must scramble to meet placed-in-service requirements in order to receive the tax credits. The reality that the PTC is never extended for more than a few 
years and that further renewal is always uncertain presents a major challenge for the industry. Geothermal development needs long-term planning and a consistent investment environment for projects to get off the ground. Industry advocates have continually urged Congress to extend placed-in-service deadlines for the PTC for at least 5 years (Gawell 2007).

\section{Appendix 2. Renewable Portfolio Standard and Geothermal Development in Nevada and California}

While wind power has been the primary beneficiary of state RPS policies so far, geothermal is also getting developed and appears likely to do well in states with known geothermal resources and with certain RPS design considerations. RPS policies encourage utilities to enter power purchase agreements with geothermal developers, and long-term contracts help geothermal projects become economically viable.

Certain design considerations in California and Nevada have indirectly encouraged contracts with geothermal power generators. First of all, RPS targets are aggressive. Cost-effective geothermal plants are larger in scale than the more modular renewable technologies, leading to their success with aggressive compliance targets. Flexibility mechanisms (e.g., banking) allow for Renewable Energy Credits (RECs) generated by a geothermal plant to be banked if the generation exceeds the scale of the annual increase in RPS targets (Wiser et al 2003). Finally, both states ensure equitable comparisons of different renewable sources, considering integration and deliverability characteristics, and call for "least-cost, best-fit" selection of renewable projects (Wiser et al 2003). In these two states, at least, geothermal fits that bill.

\section{California}

California's RPS requires load-serving entities to meet a target of $20 \%$ by 2010 and $33 \%$ by 2020. Because revisions have made the RPS increasingly stringent, development activity is set to increase. The Californian RPS has no provisions that specifically encourage geothermal, but how the RPS is implemented may implicitly encourage geothermal development (Wiser et al. 2003). In particular, the legislation requires utilities to select renewable resources on a "least-cost, bestfit" basis, including consideration of transmission and integration investments. Additionally, the legislation requires utilities to consider the delivery profile (baseload versus peaking power) of the resource.

Some analysts project California's RPS compliance scenarios with very large percentages of geothermal energy (Wiser et al. 2003). The sheer quantity of capacity under development supports the supposition that geothermal will play a large roll in reaching $33 \%$ renewable electricity by 2020. As of August 2008, 1,016.6 MW of geothermal capacity are in various stages of development in California (GEA 2008b).

\section{Nevada}

Nevada's RPS mandate was enacted in 1997, and made effective in 2001. Nevada set a high initial target for its RPS, calling for $15 \%$ of sales to be from renewable energy by 2013 . Since then, an amendment has made the mandate more stringent, calling for $20 \%$ by the end of 2015 . 
Though there are no geothermal-specific design elements, the Nevadan RPS provides indirect support to geothermal through (1) consideration of integration cost and reliability impacts, and (2) in-state renewable energy certificate trading. As in California, utilities in Nevada are bound by the public utilities commission consider all renewable resources and select contracts that combine the best combination of low-cost supply and attractive delivery profiles. Additionally, all in-state generation is eligible, and does not need to be interconnected to the utility. Thus RPS implementation has allowed for the largest utilities, Sierra Pacific Power and Nevada Power, which are not significantly interconnected to any geothermal resources, to contract with geothermal projects in northern Nevada for power. Furthermore, Nevadan geothermal resources are somewhat favored because out-of-state renewable generators (that may be less expensive) are not eligible.

Since 2005, when the first plant was completed, four new geothermal plants have been installed in Nevada with combined capacity of 76 MW (GEA 2008a). Geothermal development is likely to continue at a fast pace supported by the state's RPS until the requirements are met, especially if wind integration continues to be a concern. There are currently 42 confirmed and 3 unconfirmed geothermal projects undergoing development in the state (GEA 2008b). Total capacity of these new plants is estimated to reach between 1,083 and 1,902 MW. There are 21 early-stage projects that are securing rights, 10 projects where exploratory drilling and confirmation are underway, 6 projects that are securing power purchase agreements and final permits, and 5 projects that are currently under construction (GEA 2008b). 


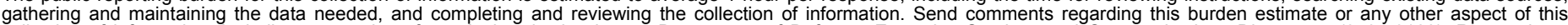

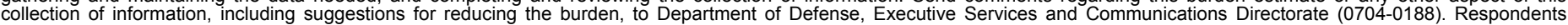

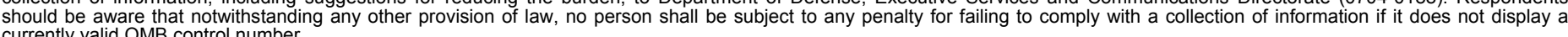

PLEASE DO NOT RETURN YOUR FORM TO THE ABOVE ORGANIZATION.

\begin{tabular}{l|l|l|l} 
1. REPORT DATE $(D D-M M-Y Y Y Y)$ & 2. & REPORT TYPE & 3. DATES COVERED (FrOm - TO)
\end{tabular} September 2009

Technical Report

4. TITLE AND SUBTITLE

Policy Overview and Options for Maximizing the Role of Policy in

Geothermal Electricity Development 5a. CONTRACT NUMBER

DE-AC36-08-GO28308

5b. GRANT NUMBER

5c. PROGRAM ELEMENT NUMBER

5d. PROJECT NUMBER

NREL/TP-6A2-46653

5e. TASK NUMBER

GT08.3000

5f. WORK UNIT NUMBER
7. PERFORMING ORGANIZATION NAME(S) AND ADDRESS(ES)

National Renewable Energy Laboratory

1617 Cole Blvd.

Golden, CO 80401-3393
8. PERFORMING ORGANIZATION REPORT NUMBER NREL/TP-6A2-46653

9. SPONSORING/MONITORING AGENCY NAME(S) AND ADDRESS(ES)

10. SPONSOR/MONITOR'S ACRONYM(S) NREL

11. SPONSORING/MONITORING AGENCY REPORT NUMBER

\section{DISTRIBUTION AVAILABILITY STATEMENT}

National Technical Information Service

U.S. Department of Commerce

5285 Port Royal Road

Springfield, VA 22161

\section{SUPPLEMENTARY NOTES}

\section{ABSTRACT (Maximum 200 Words)}

Geothermal electricity production capacity has grown over time because of multiple factors, including its renewable, baseload, and domestic attributes; volatile and high prices for competing technologies; and policy intervention.

Overarching federal policies, namely the Public Utilities Regulatory Policies Act (PURPA), provided certainty to project investors in the 1980s, leading to a boom in geothermal development. In addition to market expansion through PURPA, research and development policies provided an investment of public dollars toward developing technologies and reducing costs over time to increase the market competitiveness of geothermal electricity. Together, these efforts are cited as the primary policy drivers for the currently installed capacity. Informing policy decisions depends on the combined impacts of policies at the federal and state level on geothermal development. Identifying high-impact suites of policies for different contexts, and the government levels best equipped to implement them, would provide a wealth of information to both policy makers and project developers.

\section{SUBJECT TERMS}

geothermal energy; state policy; federal policy; geothermal electricity development; enhanced geothermal systems; investment tax credits; financial incentives; feed-in tariffs; federal funding; state funding

\begin{tabular}{|l|l|l|l|l|}
\hline 16. SECURITY CLASSIFICATION OF: & 17. LIMITATION \\
OF ABSTRACT & 18. NUMBER \\
OF PAGES
\end{tabular}

19a. NAME OF RESPONSIBLE PERSON
19b. TELEPHONE NUMBER (Include area code)

